\title{
A Brief Introduction to the Polyurethanes According to the Principles of Green Chemistry
}

\author{
Joanna Brzeska *iD and Agnieszka Piotrowska-Kirschling \\ Department of Industrial Product Quality and Chemistry, Faculty of Management and Quality Science, \\ Gdynia Maritime University, 83 Morska Street, 81-225 Gdynia, Poland; a.piotrowska-kirschling@sd.umg.edu.pl \\ * Correspondence: j.brzeska@wznj.umg.edu.pl
}

Citation: Brzeska, J.;

Piotrowska-Kirschling, A. A Brief Introduction to the Polyurethanes According to the Principles of Green Chemistry. Processes 2021, 9, 1929. https://doi.org/10.3390/pr9111929

Academic Editor: Chi-Min Shu

Received: 7 October 2021

Accepted: 25 October 2021

Published: 28 October 2021

Publisher's Note: MDPI stays neutral with regard to jurisdictional claims in published maps and institutional affiliations.

Copyright: (c) 2021 by the authors. Licensee MDPI, Basel, Switzerland. This article is an open access article distributed under the terms and conditions of the Creative Commons Attribution (CC BY) license (https:/ / creativecommons.org/licenses/by/ $4.0 /)$.
Abstract: Polyurethanes are most often called "green" when they contain natural, renewable additives in their network or chemical structure, such as mono- and polysaccharides, oils (mainly vegetable oils), polyphenols (e.g., lignins, tannins), or various compounds derived from agro-waste white biotechnology (Principle 7). This usually results in these polyurethanes obtained from less hazardous substrates (Principle 4). Appropriate modification of polyurethanes makes them susceptible to degradation, and the use of appropriate processes allows for their recycling (Principle 10). However, this fulfilment of other principles also predisposes them to be green. As in the production of other polymer materials, the synthesis of polyurethanes is carried out with the use of catalysts (such as biocatalysts) (Principle 9) with full control of the course of the reaction (Principle 11), which allows maximization of the atomic economy (Principle 2) and an increase in energy efficiency (Principle 6) while minimizing the risk of production waste (Principle 1). Moreover, traditional substrates in the synthesis of polyurethanes can be replaced with less toxic ones (e.g., in non-isocyanate polyurethanes), which, at the same time, leads to a non-toxic product (Principle 3, Principle 5). In general, there is no need for blocking compounds to provide intermediates in the synthesis of polyurethanes (Principle 8). Reasonable storage of substrates, their transport, and the synthesis of polyurethanes guarantee the safety and the prevention of uncontrolled reactions (Principle 12). This publication is a summary of the achievements of scientists and technologists who are constantly working to create ideal polyurethanes that do not pollute the environment, and their synthesis and use are consistent with the principles of sustainable economy.

Keywords: green chemistry; polyurethanes; environmental management; sustainable economy

\section{Introduction}

The history of using polyurethanes is almost as long as that of synthetic polymers, in general.

Polyurethane technology started in 1937 but developed rapidly during World War II, when polyurethane coatings were used to impregnate paper and make mustard gasresistant clothing. They have also been used in high-gloss aircraft finishes and chemical and corrosion-resistant coatings to protect metal, wood, and masonry [1].

As the name "polyurethanes" stands for a huge group of various polymers, which only have the same urethane moiety and the remaining parts of their chemical structure are completely different, the form, structure, and, above all, the properties of polyurethanes are various. Polyurethanes cover a wide group of polymers that differ in chemical structure, morphology, and even physical state, and the method of obtaining them is also completely different. Typical cast polyurethanes, elastomers, thermoplastics, etc. are obtained as a result of the reaction of the addition of isocyanate and hydroxyl groups (Figure 1), during which no by-products are formed (of course, as long as the synthesis is carried out). On the other hand, polyurethane foams are obtained in a polycondensation reaction, where the foaming agent is often water (or some low-boiling, inert solvent) that reacts with isocyanate groups to form $\mathrm{CO}_{2}$ (Figure 2). 


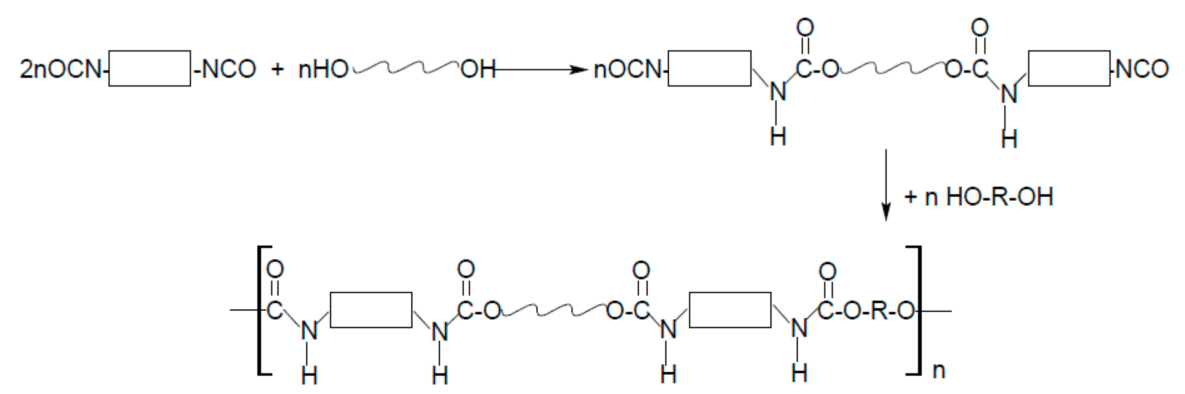

Figure 1. Scheme of polyurethane synthesis based on the example of the prepolymer method.

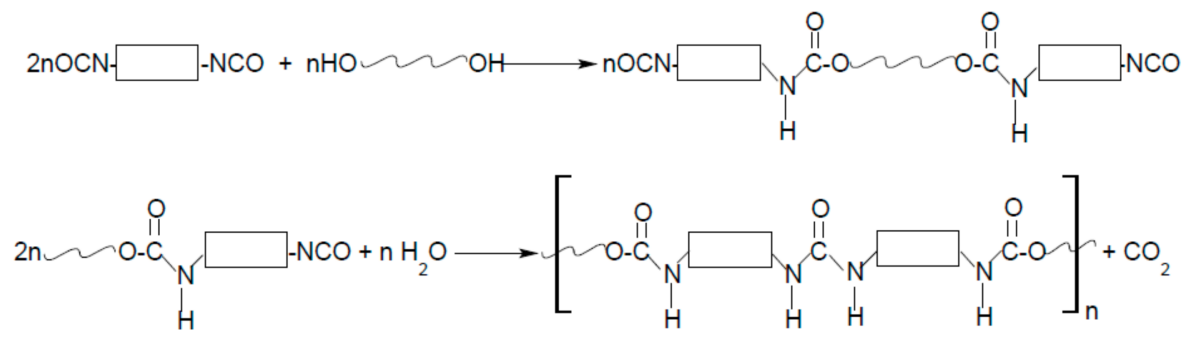

Figure 2. Scheme of polyurethane foam synthesis based on the example of the prepolymer method and with water as a foaming agent.

The rectangles, spring, and $\mathrm{R}$ in Figures 1 and 2 represent fragments of chemical compounds introduced into the structure of polyurethane with diisocyanate, polyol, and low-molecular-weight chain extender, respectively.

Because the form of polyurethanes and their properties are so diverse, the area of application is huge. The most popular examples of the use of polyurethanes that we (by "we", we mean people in general) encounter in everyday life are shown in Figure 3.

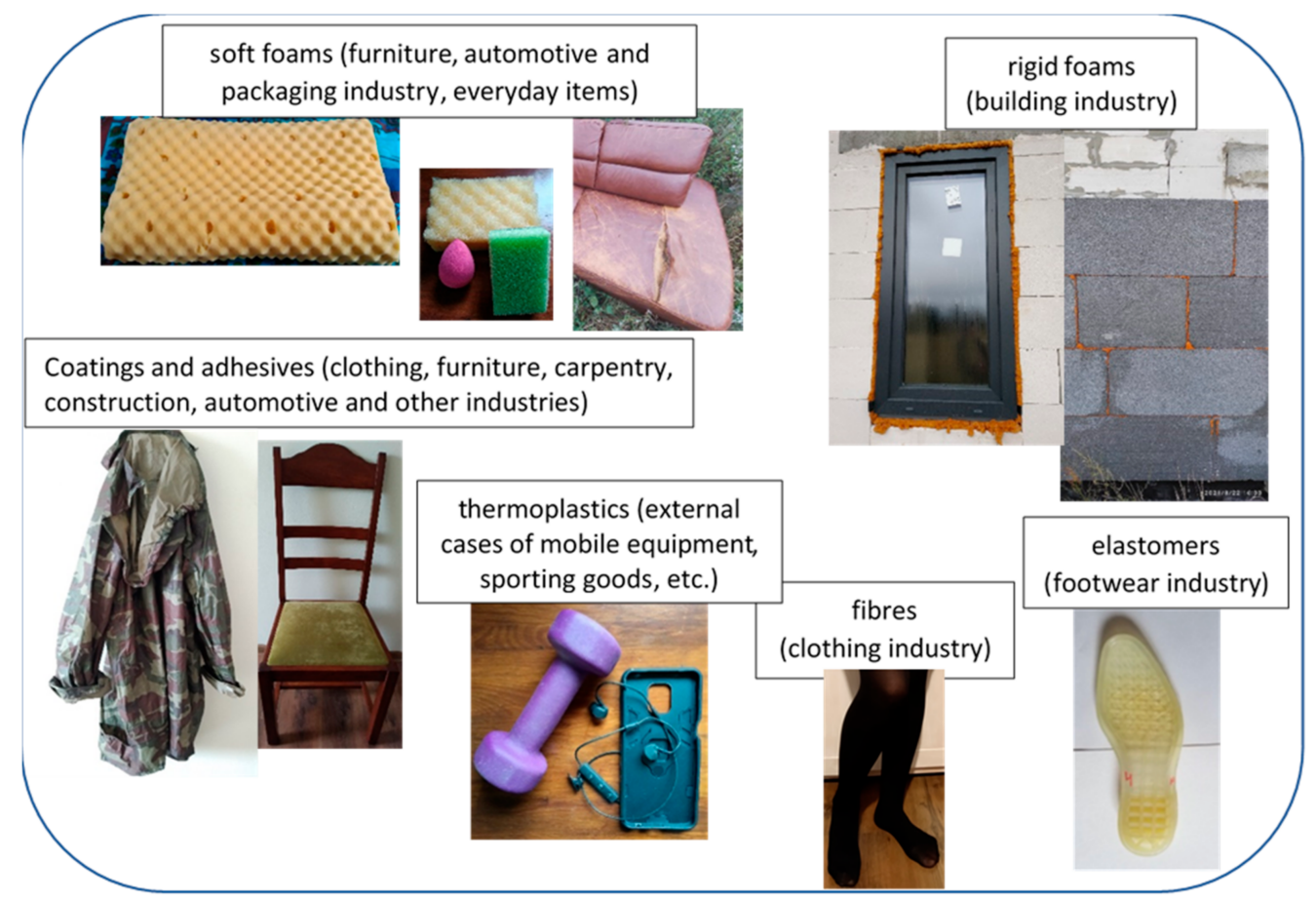

Figure 3. The most visible examples of the use of polyurethanes.

The insulating properties of polyurethane foams are known and used almost from the very beginning of their use. The foams insulate buildings thermally and acoustically. 
For some time now, polyurethane foam has also been used in car tires, which significantly reduces road noise.

The construction and furniture industries would not function properly today without rigid and flexible polyurethane foams and polyurethane coatings, adhesives, sealants, and elastomers.

The excellent properties of polyurethanes have also been appreciated by the world of sports. They are used in the construction of running surfaces that sensationally cushion the joints of runners/jumpers, in the building of mats for athletes, and in combat sports, as well as for the construction of ships and their protection against water and petrochemical compounds. However, perhaps the most important, and certainly the most obvious in everyday use by amateurs is sports clothing. The decision to withdraw polyurethane clothing for swimmers from the Olympic Games has proven how comfortable these clothes are and how they can improve the results achieved by athletes.

Clothing made of polyurethane fibers, or haberdashery or footwear made of polyurethane artificial leather are an integral part of every person's life.

Of course, one cannot fail to mention the use of polyurethanes in medicine as scaffolds for tissue growth, elements of medical equipment, and temporary and permanent implants [2-7]. The production of polyurethanes in accordance with the principles of green chemistry is undoubtedly beneficial to the environment, which is the basic assumption. However, compliance with most of these rules is a guarantee of obtaining a product of the highest quality. Current and systematic control of the course of the reaction at every stage of production or the use of specific catalysts allow for obtaining a product with the best possible properties. Moreover, the use of non-toxic substrates and solvents makes this product safe for the environment and for use by humans.

In 2006, Matsumura, Soeda, and Toshima published an interesting review on the synthesis of polyurethanes in accordance with a sustainable economy [8]. They indicated the synthesis of non-isocyanate-free, biodegradable, and lipase-synthesized polyurethanes. Where did the development of green polyurethanes go over the next 15 years?

\section{The Principles in the Green Chemistry of Polyurethanes}

In the 1990s, it was finally recognized that preventing the generation of waste at source is better for the environment than its disposal. This changed the way of thinking of decision-makers and resulted in the term "green chemistry", which became established with the formulation of the 12 principles of green chemistry in 1998 [9].

These are: 1. Prevent waste, 2. Maximize atom economy (Synthetic efficiency), 3. Design less hazardous chemical syntheses (benign syntheses), 4. Design safer chemicals and products (benign products), 5. Use safer solvents and reaction conditions (avoid auxiliaries), 6. Increase energy efficiency (energy efficiency), 7. Use renewable feedstocks (renewable feedstocks), 8. Avoid chemical derivatives (avoid protecting groups), 9. Use catalysts, not stoichiometric reagents (catalysis), 10. Design chemicals and products to degrade after use (degradation or recovery), 11. Analyze in real time to prevent pollution (real-time analysis), and 12. Minimize the potential for accidents (prevent accidents) [10,11]

The 12 principles of green chemistry are part of a sustainable economy. It is a powerful tool that can significantly improve the state of the environment. Just as we saw that the benefits of synthetic chemistry should be used wisely, the polymer industry should also be made more sustainable. After we failed on the phenomenal properties of polymers for the first time, once they had mastered almost every element of our lives, we finally began to notice that our carelessness, convenience, and mindless consumerism had turned polymer products into a giant source of garbage.

Now we know that one of the elements of environmental management is efforts to reduce the amount of waste generated by the polymer industry. As the volume of polyurethane waste is huge, which is mainly related to the number of foams used, conducting the production of polyurethanes in accordance with the principles of green chemistry gives us a chance to significantly reduce waste in the environment. Much research has 
already been conducted to make polyurethanes safer and degradable at the end of their useful life. Other principles from among the aforementioned 12 are also introduced in the production of polyurethanes, which gives hope that we will still be able to enjoy these unique materials without harming the environment and ourselves.

\section{Principle 1.}

Waste prevention is a principle that covers almost all the other 11 principles; $100 \%$ consumption of starting substrates (Principles 2 and 9) prevents the formation of waste, unusable residues of these compounds. A nuisance waste is also a solvent, which must be removed from the polymer solution after the synthesis reaction, so it is more preferable to use the solvent-free method (Principle 5). Indirectly, energy-intensive processes are also a source of waste from energy production (Principle 6). Thus, more advantageous are processes for the preparation of polyurethane products at room temperature, which do not require energy expenditure. The introduction of natural materials into the polyurethane structure or network is often the cause of the increased susceptibility of these polyurethanes to environmental degradation (Principles 7 and 10). This is the direct reason for the reduction of the amount of polymer waste deposited in the natural environment. In many cases, the utility of the product is greatly increased when the functional groups of the substrates are partially blocked. For example, the stability of powders for the production of polyurethane coatings is much higher when the isocyanate groups are blocked. Unfortunately, during synthesis, these blocking groups are waste which is often evaporated into the air (Principle 8). The solution may be intramolecular blocking. The use of catalytic reactions in polyurethane production processes is a very old practice. It has long been recognized that there is a need to accelerate the reaction between isocyanate groups and hydroxyl, amino, or carboxyl groups. Furthermore, specific reactions are directed through the selectivity of the catalysts. Thus, in general, the reactions for obtaining polyurethanes are carried out catalytically rather than stoichiometrically, thus avoiding the use of excess reactants that could constitute post-reaction waste (Principle 9). In addition to the natural additives/substrates mentioned previously, the susceptibility to degradation of polyurethanes can also be modelled by introducing into their structure degradable synthetic substrates with degradable groups (Principle 10). Strict control of the purity of the reagents, the degree of conversion of their functional groups, as well as the process parameters, on an ongoing basis during the synthesis, are necessary to obtain a good quality product (Principle 11). Any negligence in this regard results in the formation of production or usable waste. An example is the non-degreasing of the surface on which the polyurethane adhesive is applied or the addition of too much water by the workers to the system, which results in excessive swelling and bending of the joined sheets. As it can be seen in [12], most accidents with polyurethanes occurred during their use or storage due to technical failure, management failure, human failure, or deliberate action. These accidents could have been avoided if the manufacturer's recommendations for the substrates and finished products were followed (Principle 12). In Atsugi, Kanagawa, Japan, a fire started from soft polyurethane foam shortly after it was foamed in a warehouse. The nozzle that sends the raw material failed. When the work was resumed after the nozzle was cleaned, the mixing rate of the raw materials was irregular in some places, and this caused a strong exothermic reaction. The damage increased because there was no sprinkler system at the factory [13].

\section{Principle 2.}

An important issue in the design of the synthesis process of each polymer is the development of optimal reaction conditions, as well as the selection of appropriate reactants and their mutual relationship. This is to obtain the product in question with optimal performance. The most favorable situation is when all the substrate atoms are used up in the building of the final product.

As mentioned above, the polymerization efficiency may result from many factors. Palumbo et al. denoted the coupling efficiency $(R)$, that is, the ratio of the $M_{w}$ value of the 
obtained polyurethane to the $\mathrm{M}_{\mathrm{w}}$ value of the respective prepolymer [14]. They found that the highest degree of coupling was obtained for polyurethane obtained from a poly(ether ester) triblock copolymer as soft segment with a molar ratio of mol $\varepsilon$-caprolactone/mol poly (ethylene glycol) $=12$. Therefore, in this case, the effectiveness of reacting the substrates resulted from their appropriate selection. While developing the synthesis of non-isocyanate polyurethanes, Błażek et al. found that the highest degree of substrate conversion could be obtained with a molar ratio of amine/cyclic carbonate of 1.2 [15].

The degree of cross-linking determined by FTIR analysis can be correlated with the polymerization conversion efficiency. Chan et al. obtained a three-dimensional matrix of nanofibers by fast light curing during electrospinning of a polycarbonate polyurethane with a cross-linked and degradable ionomeric polyurethane [16]. They found that the degree of cross-linking (conversion) between both substrates in the electrospinning process $(94 \%)$ was comparable to the polyurethane matrix obtained by pouring into a mold (96\%). Thus, they obtained a material with the desired morphology without losing the degree of reactivity of the substrates.

\section{Principles 3 and 4.}

As early as 1951, data on the harmful effects of isocyanates on workers in industrial plants producing polyuretha nes were reported. Workers exposed to toluene diisocyanate (TDI), the diisocyanate used at the time, were found to frequently experience eye irritation, throat irritation or dryness, and/or chest tightness. There was also a nagging cough, especially at night. At that time, it was believed that all isocyanates were very toxic. Later studies among employees of polyurethane plants showed that methylene diphenyl diisocyanate (MDI) was less toxic due to its low evaporative capacity [17]. However, 4 out of 57 workers at an MDI rigid polyurethane foam plant developed isocyanate asthma [18]. As already noted, then, essentially, the problem with TDI comes from inhaling the fumes. MDI was characterized by low volatility, so that at normal temperatures there were no hazardous concentrations of vapors. It was true that the steam hazard was low, but many MDI applications involved spraying or dispensing of reacting MDI resin mixtures, and a hazardous aerosol would be generated. This could result in the inhalation of fine droplets containing unreacted MDI, resulting in varying degrees of respiratory irritation, sometimes with asthmatic breathing. Already in the 1960s, aliphatic diisocyanates, such as hexamethylene diisocyanate (HDI), were thought to be mainly directly irritating (to the skin and eyes), while aromatic diisocyanates, if less directly irritating, were more prone to causing allergies. It was known that HDI was as volatile as TDI, which also influenced its allergenic effect.

Generally, isocyanates are considered to be powerful respiratory allergens. In addition, they can also cause hypersensitivity pneumonia, contact dermatitis, and rhinitis [19].

However, as early as 1963, it was reported that existing systems for the production of polyurethane coatings contained a very low (approximately $0.5 \%$ ) content of free isocyanate, which virtually eliminated the toxic effect. Of course, these studies did not show the hazardous conditions of workers in the isocyanate plant.

Later years have shown that events occur from time to time indicating the toxic effects of isocyanates. Two pigeon breeders lost their chicks (about 225) after replacing the nesting material [20]. Their autopsy revealed they had dark and wet lungs. It turned out that TDI and MDI were detected in the nesting stocks. Similar symptoms were found in many species of mammals (mice, rats, guinea pigs, rabbits, and dogs).

The World Health Organization reported that the LC 50 for a single 4-h exposure by inhalation TDI assessed 14 days after exposure ranged from 10 to 14 ppm in mammals. Regulatory agencies such as the Occupational Safety and Health Administration (OSHA) and the American Conference of Governmental Industrial Hygienists (ACGIH) have set exposure limits in the range of 0.005 to $0.02 \mathrm{ppm}$. Current research has confirmed that MDI is less toxic than TDI [20]. 
Fortunately, SafeAir isocyanate detectors and aromatic isocyanate identifiers are now commercially available.

The threats related to the use of isocyanates in the production of polyurethanes, observed since the middle of the last century, resulted in the introduction of other methods of obtaining these polymers.

The most common methods for obtaining a urethane moiety are the aforementioned reaction of an isocyanate with a polyol or a diol, as well as the reaction of a carbamic acid derivative with a hydroxyl compound and a carbonic acid reaction with an amine (Figure 4) [21].

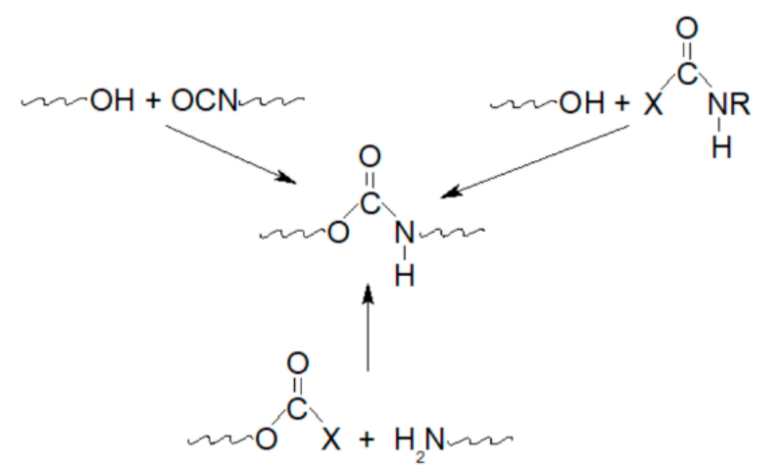

Figure 4. Schemes of the easiest ways to obtain urethane moieties (where $\mathrm{X}$ could be $\mathrm{Cl}, \mathrm{OR}^{\prime}$, $\mathrm{NR}^{\prime} \mathrm{R}^{\prime \prime}$, or $\mathrm{SR}^{\prime}$ ).

Additionally, as pointed out by Matsumura, there are many different carbamic and carbonic acid derivatives that can be used to make polyurethanes without using diisocyanates [8]: (1) as early as 1953 it was possible to obtain urethane diols by reacting a cyclic carbonate with an amine, which was then subjected to a polycondensation reaction with acids; (2) difunctional cyclic carbonates were subjected to a polyaddition reaction with diamines; (3) polyaddition of L-lysine hydrochloride and a difunctional five-membered cyclic carbonate were used to obtain the dihydroxy- and carboxy-polyurethane; (4) polyaddition of the mentioned cyclic carbonate with diamine was also used; (5) polyurethane can be synthesized from ethylene carbonate, diamine, and diols (6), or by ring-opening polymerization (7) and also by copolymerization of 2,2-dimethyltrimethylene carbonate with tetramethylene urea. It is also very interesting to obtain polyurethane as a result of the reaction of 2-methylaziridine and supercritical carbon dioxide [8].

As Waghmare and Mahanwar indicated, the most promising method is the synthesis of polyurethanes with cyclic carbonates [22]. Five-membered cyclic carbonate appears to be the most preferred for its safe and economical preparation process. In this reaction, the nucleophilic amine on the cyclic carbonate carbonyl causes the ring opening to form a carbamate bond and a pendant hydroxyl group. This reaction is much less sensitive to water than the traditional isocyanate method. To overcome some of the limitations of non-isocyanate polyurethanes, such as poor room temperature curing and processing difficulties due to high viscosity and poor solubility, often found with cyclic carbonate resins, special additives are used [23]. Gomez-Lopez et al. found that the combination of the adhesion promoter (dopamine) and the fast-curing promoter (aminopropyltrimethoxysilane) greatly accelerated the reaction of the trifunctional five-membered cyclic carbonate with the aromatic diamine, yielding non-isocyanate polyurethane adhesives that retained adhesion to a variety of substrates [24].

In the thiol-en method, in the copolymerization reaction of carbamate, urea, and dithiol to a non-isocyanate polyurethane, the authors obtained additional macromolecules, i.e., polyureas and copolymers, from reaction by-products [25]. In this way, they minimized the amount of waste and improved the sustainability of the method.

A very interesting idea was proposed by $\mathrm{Wu}$ et al. to obtain a self-healing nonisocyanate polyurethane elastomer based on bis(6-membered cyclic carbonate) and aminoterminated liquid nitrile rubber [26]. Additionally, it is advantageous from an environ- 
mental point of view insofar that it is possible to recover $75 \%$ of the pure monomer (di(trimethylolpropane)) from this material after acid degradation. Additionally, selfhealing non-isocyanate polyurethanes were synthesized by Wang et al. [27]. These soft and rubbery cross-linked polyurethanes, obtained by a ring-opening reaction of diglycerol bis(cyclic carbonate) with isophoronediamine and furfurylamine, had 100\% self-healing efficiency.

According to Wolfgang et al., thermoplastic non-isocyanate polyurethanes with interesting properties can also be obtained as a result of polycondensation of the $1,1^{\prime}$ carbonyldiimidazole derivative with amines [28]. The resulting polyurethanes are characterized by high thermal stability, adjustable glass transition temperature, the introduction of flexible polyether segments, and the formation of mechanically ductile thin layers.

Another type of polyurethane material that can also be obtained without the use of isocyanates are coatings. Boisaubert et al. obtained polyurethanes with mechanical properties comparable to the isocyanate polyurethane coatings available on the market [29]. The coatings obtained from fluorine-containing cyclic carbonates were characterized by very low water absorption, excellent hydrophobic/oleophobic properties, and corrosion resistance [30]. Very special requirements are placed on coatings for aviation and aerospace. Here, performance properties such as flexibility in sub-zero temperatures and good chemical resistance are extremely important. Zareanshahraki et al. synthesized a series of durable, UV-curable, non-isocyanate-urethane-acrylate oligomers with different structures and acrylate equivalents, which were then used as the basic building block of UV-curable coatings [31]. The presented results showed that these coatings are flexible at $-54{ }^{\circ} \mathrm{C}$ and have good chemical resistance; therefore, they are a great alternative to classic isocyanate polyurethanes. Additionally, according to Kanchana, the non-isocyanate coating is more hydrolytically stable, and has increased adhesiveness, abrasion resistance, and chemical resistance compared with conventional polyurethane systems [32].

Foams are also produced without the use of isocyanates [33]. To increase the reactivity of the five-membered cyclic carbonates in the non-isocyanate polyurethane reaction, additional chemicals can be added to create hybrid materials with excellent performance.

Additionally, these non-isocyanate polyurethanes can also be obtained from substrates derived from natural sources. Kanchana indicates the use of epoxidized soyabean oil in the production of non-isocyanate polyurethanes by various means, as well as derivatives of linseed or soyabean based oil [32]. In addition, they are modified with nanoparticles, which also improves selected properties, including biocidicity.

Another example of a bio-based non-isocyanate polyurethane is a membrane obtained from a soybean oil derivative [34]. Soybean oil with cyclic carbonate groups was prepared by reacting of epoxidized soybean oil with carbon dioxide gas, and the product was then reacted with tetraethylenepentamine followed by treatment with epichlorohydrin. These membranes have been shown to be non-cytotoxic to fibroblast cells and effectively antibacterial against gram-negative and gram-positive bacteria, which may provide a hygienic environment for cell growth and proliferation over injured skin tissue.

Non-isocyanate polyurethanes can be processed by well-known classical techniques such as extrusion and injection molding, but also by electrospinning and 3D printing, and by methods leading to scaffolds and porous materials. Thanks to this, they can have very wide applications such as in thermosetting coatings, UV-resistant coatings, monolithic floors, and also in the biomedical sector [35].

As isocyanates are extremely sensitive to water, their non-use in the synthesis of polyurethanes increases the stability of the substrate system, thus reducing potential waste.

\section{Principle 5.}

The use of solvent-free methods is the most optimal way to prevent the problem of solvent evaporation, condensation, and purification. However, in some cases, it is more preferable to carry out the reaction in a solvent due to better mixing of the substrates and the kinetics of the addition process. 
There is a large group of polyurethanes that are obtained without the use of organic solvents. These include non-isocyanate polyurethanes and waterborne polyurethanes.

Błażek et al. performed the synthesis of environmentally friendly non-isocyanate polyurethanes by polyaddition of a cyclic carbonate based on polyether polyol with a diamine derivative of dimerized fatty acids [15]. The process was carried out without toxic solvents, and the obtained materials were characterized by good thermal stability. Solventfree non-isocyanate polyurethanes were also prepared by Wołosz et al. [36]. These aliphatic and aliphatic-aromatic poly(carbonate-urethanes) exhibited tensile strengths higher than $40 \mathrm{MPa}$ and $50 \mathrm{MPa}$, respectively.

As the requirements for the use of solvent-based coatings are becoming more and more restrictive, there are increasing numbers of water-based adhesives, paints, and varnishes are available on the market. The undeniable benefit is their much greater safety for the environment and living organisms. Kohale compared the basic parameters of waterborne polyurethane paints with solvent-based paints [37]. He found them: to contain more solids ( $40-50 \%$ versus $15-18 \%$ ) and aliphatic isocyanates (versus aromatic); they are non-toxic (versus toxic); do not poison the environment (versus poison); however, they have longer drying times (requiring more energy), lower temperature stability, and require additional crosslinking agents; however, like solvent-based paints, they have excellent adhesion properties. These waterborne polyurethanes have been on the market since the beginning of the 1980s, so the level of research on them is well advanced [37].

Agnol et al., in their paper, provided extensive answers to questions about the preparation and application of waterborne polyurethane coatings prepared as a result of UVinduced photoreaction, e.g., "Which monomers were most often used in the synthesis of UV-waterborne polyurethane?"; "What type of photoinitiator promoted the most efficient material curing?"; "Which additives or particles have been tested for Composite UV-waterborne polyurethane?"; "Which applications are UV-waterborne polyurethane aimed at?" [38]. The authors indicated that such a wide use of UV-waterborne polyurethane materials, i.e., as antibacterial, antistatic, flame retardant, and anti-fog coatings to protect or beautify the surface of wood, plastic, metal, and paper, is due to, inter alia, with the appropriate selection of nanoparticles, additives, monomers, chain extenders, and reactive diluents. They also emphasized that, apart from the fact that the synthesis of these polyurethanes is based on water without organic solvents, it also uses a fast, energy-saving, and cleaner source of curing, which is UV radiation, making these polyurethanes even more "green".

The UV-cured cationic waterborne polyurethane obtained using the partially sustainable raw material $\mathrm{CO}_{2}$ provided excellent water resistance in corrosive media for a long time (retention of tensile strength above $90 \%$ for $336 \mathrm{~h}$ ) due to its hydrolysis-resistant structure, such as carbonate and ether units [39]. Meanwhile, Wei et al. obtained waterborne polyurethane with high water resistance and high mechanical strength [40]. The reason for such properties was the high crystallinity of the materials. Zhang et al. believe that poly(hexamethylene guanidine hydrochloride) waterborne cationic polyurethane will have great potential for application as an antibacterial material in the fields of textiles, leather, medical processing, and coatings [41]. The water resistance of the coating is also important in cosmetic applications, e.g., in nail varnishes. As indicated by Peng et al., waterborne polyurethane modified with silane coupling agent showed favorable filmforming properties, gloss, flexibility, hardness, and adhesion and can be used to develop an environmentally friendly aqueous nail varnish [42]. The wood protection coating was made of water-soluble polyurethane-acrylate, where the polyurethane chain was extended with dithiol instead of diamine and finished with hydroxyethyl acrylate, which reduced the water absorption rate and improved mechanical properties at the same time [43]. $\mathrm{Xu}$ et al. significantly improved the hydrophobic and mechanical properties of aqueous polyurethane films by using triazine-based fluorine-containing diol for their synthesis [44]. The hydrophobicity of the coatings was also obtained by introducing $\alpha, \omega$-dihydroxypropyl poly(dimethylsiloxane) [45] or a fluorocarbon chain [46] into the structure of the waterborne 
polyurethane. Fluorocarbon chain in the polyurethane structure also induced anti-fouling properties of coatings [46]. Longfang et al. obtained waterborne polyurethane based on functionalized dopamine, which significantly increased its adhesion to the iron surface [47]. The adhesive properties are also used in anti-corrosion applications. Wang et al. obtained crosslinked fluorinated acrylate modified waterborne polyurethane, which protected the metal even in $3.5 \% w / w \mathrm{NaCl}$ solution [48].

In addition, waterborne polyurethanes are obtained with the participation of renewable compounds, such as castor oil [49], terpenes [50], and others. For example, with the help of cellulose nanofibrils, it is possible to improve the rheological properties of waterborne polyurethane and thus obtain 3D structures with wide new applications in the field of biomaterials [51].

Another way to influence the properties of waterborne polyurethane is their modification with nanoparticles. It turned out that nanoparticles of polyurethane-modified silica, incorporated into water-soluble polyurethanes, can not only provide the obtained composites with a good anti-reflection function, but also improve their mechanical, thermal, and water resistance [52]. Waterborne polyurethane functionalized with graphene showed excellent protection of fabrics against UV radiation and was characterized by antibacterial properties [53]. This material has been named by the authors as a selectively hydrophilic coating.

Another interesting way to eliminate classic organic solvents is the use of supercritical fluids. Their impact on the environment is negligible, and their dissolution efficiency is very high. Smith et al. compared the efficiency of organocatalysts in the polyurethane preparation reaction using supercritical $\mathrm{CO}_{2}$ as a solvent [54]. Whereas, Ihata et al. used supercritical $\mathrm{CO}_{2}$ to dissolve aziridine and at the same time as a substrate in a copolymerization reaction to form an isocyanate-free polyurethane [55]. Supercritical fluids are also used as blowing agents in the preparation of polyurethane foams, instead of the traditional, often toxic, gases. Mainly $\mathrm{CO}_{2}$ [56-61], but also, for example, $\mathrm{N}_{2}[58,62]$ are utilized for polyurethane synthesis. Supercritical solvents are even used to remove residual blowing agents, such as chlorofluoroalkanes [63].

Chen et al. showed that foaming with supercritical $\mathrm{N}_{2}$ with full temperature and pressure control (using gas back pressure) leads to more regular pores (Figure 5) [64].

a

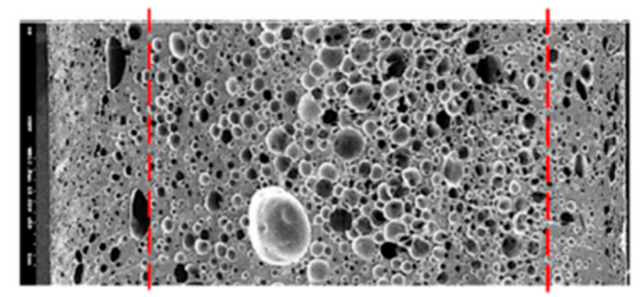

b

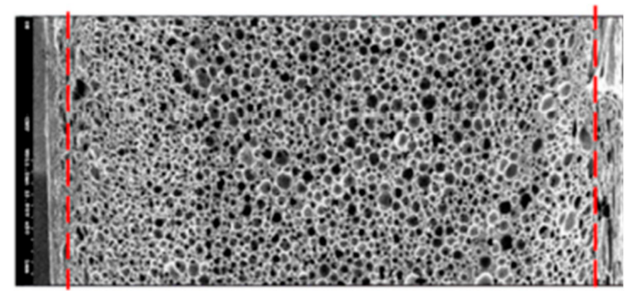

Figure 5. SEM images of the polyurethane foams without (a) and with (b) full temperature and pressure control [64].

Another application of supercritical fluids is their use for the analysis of polymers, including polyurethanes, e.g., in chromatography with Evaporative Light Scattering Detection (SFC-ELSD) for the determination of oligomer molecular weight distributions [65].

\section{Principle 6.}

The energy demand of the synthesis conducted is a very heavy burden on the environment. The most optimal solution is to carry out the reaction at room temperature and using atmospheric pressure. However, the kinetics of many reactions require the supply of an appropriate amount of activation energy to cross the energy barrier. Therefore, methods for carrying out a given process that allow one to reduce energy consumption are sought.

Biswas et al. found that the microwave-assisted reaction is a much more efficient method of producing cyclodextrin-based polyurethanes [66]. The authors obtained polyurethanes 
(e.g., from MDI) with the use of microwaves, reducing the heating time from $20 \mathrm{~min}$ in the case of conventional heating to even 3-6 min with the use of microwave, with a simultaneous $98-100 \%$ efficiency, which, in the case of the traditional method, was $83 \%$.

As mentioned earlier, the process of obtaining non-isocyanate polyurethanes from a cyclic carbonate based on a polyether polyol with a diamine derivative of dimerized fatty acids was carried out without toxic solvents [15]. Moreover, importantly, the carbonation process used as one of the steps did not require the use of increased pressure, which provided an energy gain.

An example of a process to simplify the reaction and reduce the number of intermediate steps while at the same time reducing the amount of energy consumption is the reaction to obtain oligoetherols used in the synthesis of polyurethane foams with increased thermal resistance. Examples of such a complicated synthesis are the following reactions: carbazole reaction + glycerol epichlorohydrin -> opening of the epoxy ring of 9-(2,3-oxypropyl)carbazole with water, ethylene glycol or ethanolamine -> conversion by reaction with oxiranes $->$ difunctional oligoetherols. Other methods include: reaction of carbazole with ethylene chloride $->$ reaction with diethanolamine $->$ reaction with oxiranes $->$ oligoetherols [67]. However, Lubczak proposed a simpler method: carbazole with an excess of glycidol and then with oxiranes or alkylene carbonates [67]. The reaction runs without a catalyst, and as it is exothermic, it does not need temperature control. Therefore, it is energetically beneficial.

\section{Principle 7.}

A common and ecologically beneficial direction of research is the replacement of traditional substrates, derived from crude oil, with compounds derived from renewable sources. This trend is also visible in the synthesis of polyurethanes. This issue has already been partially discussed in the section Principles 3 and 4.

Both synthetic isocyanates and low-molecular-weight diols, and above all polyols, are replaced with compounds of natural origin. Boisaubert et al. showed that it is possible to obtain polyurethanes with an almost $100 \%$ level of biological carbon and having thermal and mechanical properties comparable to commercial polyurethanes [68].

As it was shown in great detail by Peyton and Avérous, the main natural compounds used in the synthesis of polyurethanes come from: mono- and polysaccharides, oils (mainly vegetable oils), polyphenols (e.g., lignins, tannins), or various compounds derived from agro-waste white biotechnology [69].

The most popular substrates of natural origin in the synthesis of polyurethanes are polyols. Bio-based polyols are usually obtained from vegetable oils, lignocellulose, carbohydrates, and proteins [70]. They have been already used for many decades, mainly to obtain foams and coatings. To convert oil to polyol, thiol-ene coupling, ozonolysis, hydroformylation, photochemical oxidation, epoxidation, and ring opening reactions are used [71].

As shown by Llevot and Meyer in their study on the perspectives for polyurethane biocoatings, coatings synthesized from biopolyols showed excellent coating properties in terms of adhesion, impact resistance, flexibility, and gloss [72].

Biopolyol obtained from castor oil and glycerol, and used for the synthesis of polyurethane, turned out to be an excellent carrier for the lipase catalyzing, e.g., in converting chicken fat into fatty acid methyl esters [73]. Among all oils, only a few, such as lesquerella and castor oils (Figure 6), naturally contain hydroxyl groups that allow them to react with isocyanate groups $[74,75]$.

Others often used to obtain biopolyols are palm oil [76], soybean oil $[77,78]$, or canola oil [79].

There are also patents relating to the receipt of polyurethane from vegetable oils, for example, patent WB's from 2001, claiming the use of soybean oil, as well as the ability to use other oils, such as palm oil, safflower oil, sunflower oil, canola oil, rapeseed oil, cottonseed oil, linseed, and coconut oil for polyurethane foam synthesis [80]. 


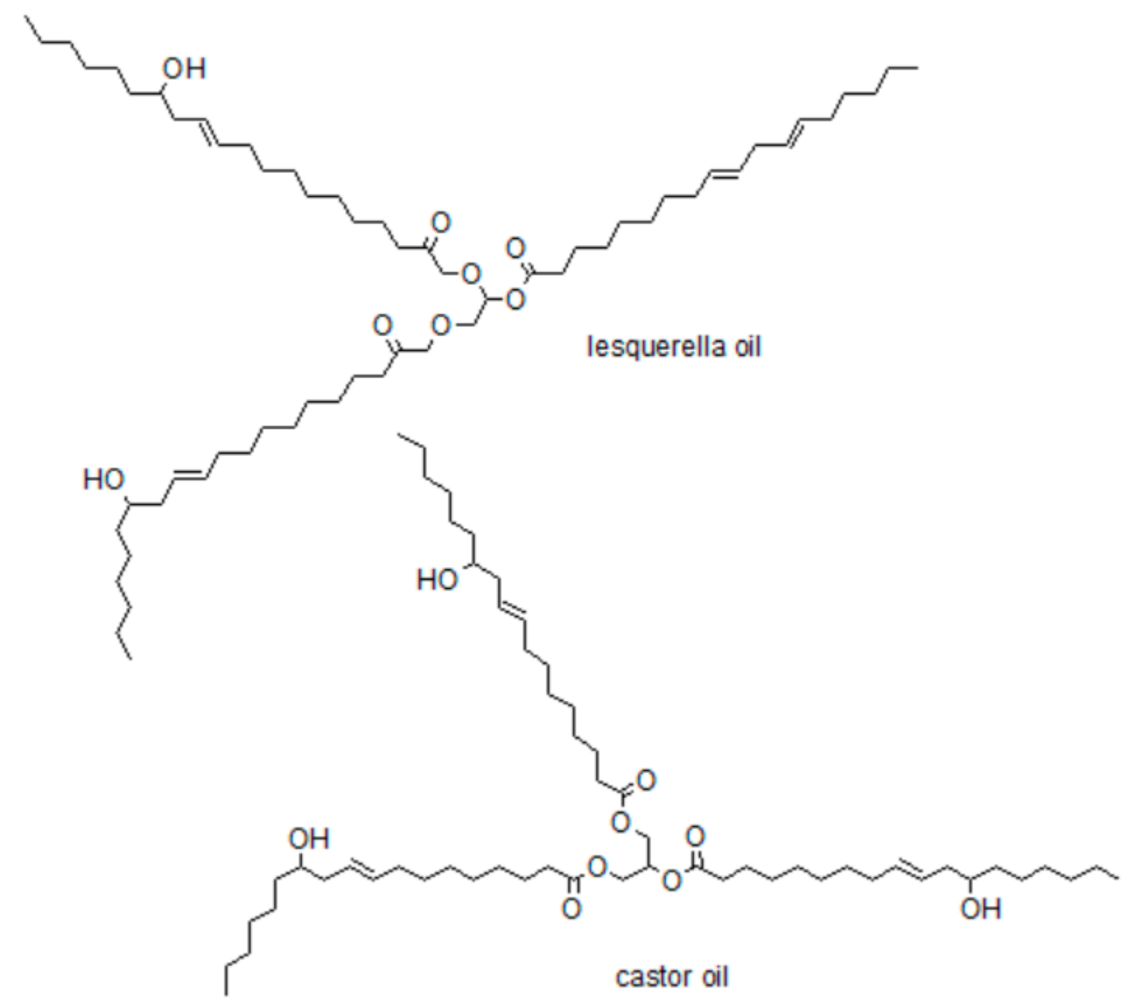

Figure 6. Scheme of lesquerella and castor oils.

Most of these natural polyols are developed in a laboratory or pilot plant scale. However, there are also commercial products already available on the market, for example, soybean derivatives. Many companies offer bio-based polyols, such as BASF (Sovermol ${ }^{\circledR}$ ), Mitsui Chemicals (ECONYKOL ${ }^{\mathrm{TM}}$ —based on castor seeds), Rampf Group (polyols based on rapeseed oil), and Bio Based Technologies (formerly Cargill) (series of Agrol ${ }^{\circledR}$ —soybean oil-based polyols), and others, which can be used for the synthesis of polyurethane.

A promising direction is the preparation of non-isocyanate polyurethanes from polyphenols (e.g., lignins and tannins). As described in their extensive work by Aristris et al., between the carboxyl groups of lignin and tannin derivatives and the amino groups of diamines, there is a polycondensation reaction with the formation of a urethane group (Figure 7) [81]. The authors showed that the adhesives obtained in this way have good properties as an alternative to petroleum-based adhesives. These bio-based polyurethanes are characterized by increased strength, low hardening temperature, shorter pressing time, and very often they are materials with thermal stability enhancement owing to the presence of aromatic lignin and tannin. Polyurethane coatings with high transparency and flexibility, as well as antioxidant capacity, were also obtained by a conventional method in the MDI reaction with lignin [82].

Isocyanates can also be obtained from natural compounds. There are known L-Lysine diisocyanates (LDI) [83] and diisocyanates based on fatty acids [71]. As Gu and Sain reported in their study on biobased polyurethanes, the structures of bioisocyanates made of fatty acids from linseed, safflower, and tall oil were identical to those of diisocyanates obtained by methods with phosgene and azide [84].

Covestro's Desmodur eco N 7300, launched in 2015, is one of the most popular natural diisocyanates. This aliphatic pentamethylene diisocyanate is made from fodder maize starch [72]. The structure of typical bio-isocyanates is presented in Figure 8.

Polyurethanes are also modified with various natural fillers in the form of fibers, particles, or nanoparticles. 
a)<smiles>COC(=O)Oc1ccc(C(O)C(CO)Oc2c(C)cc(C)cc2OC(=O)OC)cc1OC(=O)NCCCCCN</smiles>

b)<smiles>COC(=O)Oc1cc(C)cc(OC(=O)OC)c1O</smiles><smiles>COC(=O)Oc1cc(C(=O)O)cc(OC(=O)NCCCCCCNC(=O)Oc2cc(C(=O)O)cc(OC(=O)OC)c2OC(=O)OC)c1OC(=O)OC</smiles>

Figure 7. Scheme of non-isocyanate polyurethane obtaining from derivatives of lignin (a) and tannin (b).<smiles>CC(=O)OCC(CCCCCN=C=O)N=C=O</smiles><smiles>O=C=NCCCCC(N=C=O)C(=O)OCCN=C=O</smiles><smiles>O=C=NCCCCCn1c(=O)n(CCCCCNC=O)c(=O)n(CCCCCNC=O)c1=O</smiles>

Figure 8. Schemes of the most popular biobased isocyanates: L-Lysine ethyl ester diisocyanate (LDI), L-Lysine ethyl ester diisocyanate (LTI), and Desmodurßeco N 7300.

The creation of polyurethane composites with natural fillers, apart from the benefits of their biodegradability, also has a huge economic aspect. Bio-fillers are often waste materials, so they do not add any (or only minimal) cost to the production of polyurethane material. Moreover, it is very often found that they can improve some properties of a composite relative to pure polyurethane. As $\mathrm{Gu}$ and Sain indicated, the introduction of wood fiber can increase the compressive strength of polyurethane foam, as well as its thermal stability [84].

Da Silva et al. used dog wool fibers to obtain insulating polyurethane foam [85]. The authors concluded that the presence of alkaline treated fibers improved the mechanical, hydration, and heat capacity of the foams. Figure 9 shows the starting substrates and the finished foam with dog wool fibers. 


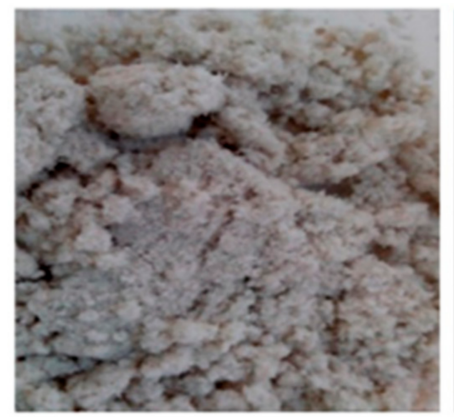

a

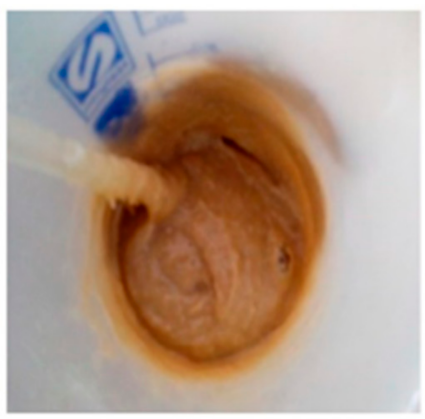

b

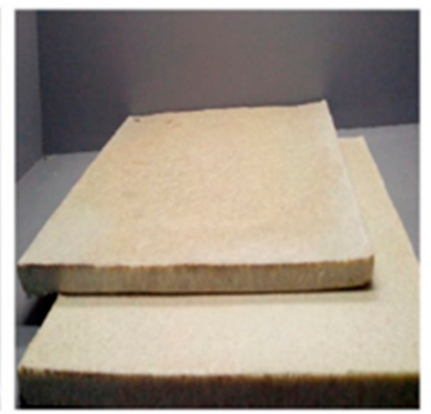

C

Figure 9. Fiber microparticles (a), mixture of polyurethane resin and the fiber microparticles (b), and the eco-composite (c) [85].

Waterborne polyurethanes, reinforced with enzymatically obtained cellulose nanocrystals, are another proposal of a green material [86]. The obtained coatings were characterized by high abrasion resistance, and the fibers obtained from these materials retained their structure for a long time during washing.

Another group of natural materials that are used to obtain polyurethanes is biomass. Biomass can be converted into biofuels and chemicals using mechanical, thermochemical, biochemical, and chemical techniques. It is known to contain only negligible amounts of sulfur, nitrogen, and ash, and therefore causes lower emissions of $\mathrm{SO}_{2}, \mathrm{NOx}$, and smoke [87].

It was proved that the composition of eucalyptus bio-oil, formed as a by-product in the production of charcoal, contained only a small amount of volatile polyaromatic substances [88]. Therefore, it is a much greener substrate than the conventional petroleum polyols used in polyurethane synthesis.

The biomass substrates used for the synthesis of polyurethanes may be liquefied: lignocellulose, sugarcane bagasse polyol, soybean straw glycerol, and waste-paper polyols [87].

Sarojini et al. combined both the oil (Mahua oil) and the carbohydrate (chitosan) substrates in one polyurethane material, and additionally modified it with $\mathrm{ZnO}$ nanoparticles [89]. As a result, they obtained food packaging films, which, after 28 days of incubation in soil, underwent $86 \%$ biodegradation. These films also significantly extended the shelf life of vegetables.

Polyurethanes can also be used to modify starch to create hybrids with properties significantly improved relative to those of the biopolymer. Ghasemlou et al. proved that the interactions between starch particles and non-isocyanate polyurethane chains are noncovalent - they are hydrogen-type interactions [90,91]. The authors point out that, with a simple method, next-generation sustainable hybrid materials with adjustable functions can be designed and implemented.

The discussed research results mostly concern polyurethane material obtained at the laboratory or semi-technical level. However, ready-made polyurethanes based on natural substrates are already available on the market. For example, the aliphatic STABiO ${ }^{\mathrm{TM}}$ based on bio-based 1,5-pentamethylene diisocyanate $\left(\mathrm{STABiO}^{\mathrm{TM}} \mathrm{PDI}^{\mathrm{TM}}\right)$ from Mitsui Chemicals are available.

\section{Principle 8.}

Usually, there is no need to use any functional group blocking compounds during the synthesis of polyurethanes, which does not generate additional production waste. However, in some cases, the use of blocking agents is necessary. It increases the durability and stability of the substrate system when the polyurethane is obtained, e.g., by the user directly on the bonded or protected surface. This applies to adhesives, coatings, and polyurethane assembly foams. It also allows for increasing the durability of semi-finished products and extending their use time. Consequently, globally, this material is less wasted. 
Isocyanate blocking agents also reduce their toxicity. As Xiang extensively described, blocked isocyanates are formed either by reacting isocyanates with blocking agents or reacting carbonates with amines [21]. The blocking and dissociation reactions of blocked isocyanates are reversible. The transition from one reaction to another depends on the ambient temperature, the added catalyst, the solvent, the type of blocking group, as well as the presence of a nucleophilizing agent, e.g., a hydroxyl or amine compound [21].

\section{Principle 9.}

Although isocyanate groups are very reactive and often do not need the support of a reaction catalyst, they are used to drive a given reaction, thereby reducing the risk of a waste polymer material with inferior properties. For example, when tertiary amines are used, the reactions of NCO groups with water are catalyzed, while the introduction of organic metallic salts causes faster reactions of NCO groups with $\mathrm{OH}$ groups.

The selection of an appropriate catalyst allows for the control of specific reactions, e.g., Kiss et al. found that by using N,N0-bis[3-(dimethylamino) propyl]urea as a catalyst instead of the traditional amine catalyst, a 3-fold greater amount could be introduced into the structure of polyurethane foams recycled polyol, obtaining a product of very high quality [92]. As can be seen in the SEM images (Figure 10), there is no difference between the pore morphology of the foam obtained with classic polyols and with conventional amine catalyst, and in recycled polyols using catalyst $N, N^{\prime}$-bis[3-(dimethylamino)propyl]urea. Furthermore, as author stated, using this selected amine catalyst can also generate the reduction of the emission of the total volatile organic compounds from $102 \mathrm{ppm}$ (using the reference polyol) to $41 \mathrm{ppm}$.
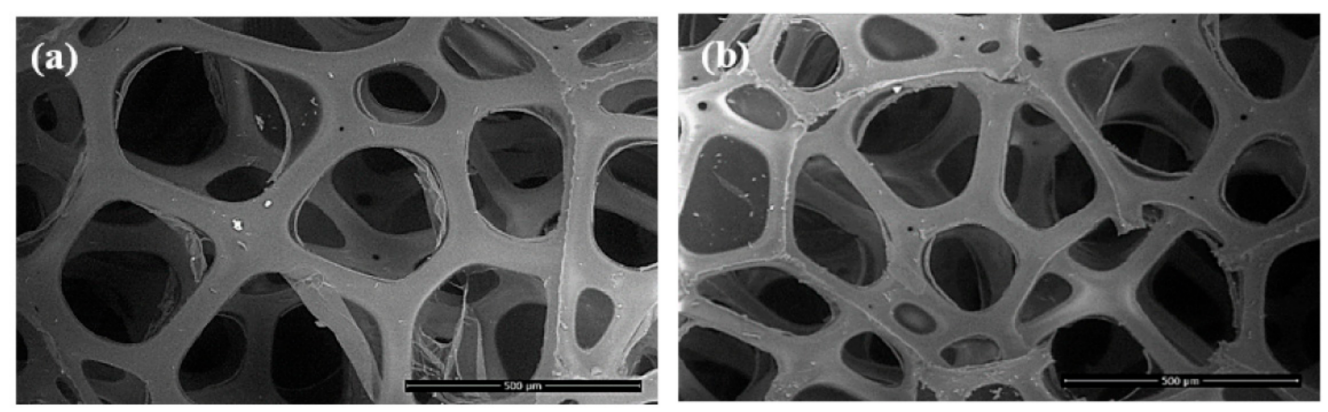

Figure 10. SEM images of the cellular structures of polyurethane foams obtained with reference polyol (a) and 30\% recycled polyol (with $N, N^{\prime}$-bis[3-(dimethylamino)propyl]urea) (b) [92].

The possibilities of using enzymes not only as polymerization catalysts, but also in the preparation of polymerization monomers or oligomers for block copolymerization were extensively discussed by Nikulin and Švedas [93].

In addition, the polyols used for polyurethane synthesis can be obtained with the use of biocatalysts. Bresolin et al. synthesized a biopolyol through the enzymatic glycerolizes between castor oil and glycerol, catalyzed by the lipase [94]. De Lima et al. call these kinds of triglycerides as the fully "green" material [95]. The triglyceride hydrolysis or glycolysis reaction was carried out without an organic solvent, at only slightly elevated temperatures, and primarily with lipase as a biocatalyst. These processes were monitored online by NMR and HPLC. By the addition of diisocyanate at various stages of hydrolysis, polyurethanes with different glass transition temperatures were obtained.

An interesting oligoester for polyurethane synthesis was obtained by Baraldi et al. [96]. Using the catalyst Lipase B Candida antarctica, they obtained oligoesters of 1000 Da by selective esterification of primary $\mathrm{OH}$ groups in 5,5'-dihydroxymethylfuroin with diethyl esters of succinic and sebacic acids. Another lipase (Eversa ${ }^{\circledR}$ Transform 2.0) was used as a catalyst for enzymatic glycerolizes of castor oil and mono- and diacylglycerol in a solventfree system [94]. This product was used as a stabilizer and biopolyol in the synthesis of an aqueous dispersion of poly(urea-urethane) nanoparticles by means of the miniemulsion 
polymerization technique, and without the use of an additional surfactant in the system. As a result of the reaction, stable dispersions of nanoparticles with an average diameter of $190 \mathrm{~nm}$ were obtained. Arrieta et al. synthesized oligomeric PCL-diol using biocatalysis with immobilized Yarrowia lipolytica lipase and diethylene glycol as initiator [97]. They obtained polyurethane from these PCL-diol and hexamethylene diisocyanate. Moreover, they obtained a second type of polyurethane by including the amino acid L-lysine as the end group, which significantly increased the susceptibility of this material to degradation.

Hayashi et al. produced non-isocyanate polyurethanes by the reaction of phenyl carbonate with amino acids and amino alcohols that produced urethane-containing diacids and hydroxy acids, respectively [98]. The urethane diacid underwent polymerization with polyethylene glycol and $\alpha, \omega$-alkanediols. The obtained urethane-containing hydroxy acid monomer was polymerized by lipase to produce high-molecular-weight poly(esterurethane)s. Due to the fact that ester bonds were introduced into the polyurethane chain by lipase-catalyzed polymerization, chemical recycling centers were created. They were readily depolymerized in the presence of lipase to cyclic oligomers, which were then readily repolymerized in the presence of the same enzyme. The symmetrical structure of these poly(ester-urethane)s resulted in them exhibiting higher values of $\mathrm{T}_{\mathrm{m}}$, Young's modulus, and tensile strength.

As indicated by Skoczynski et al., enzymatic cross-linking of polyurethanes can open up a pool of new cross-linking possibilities and related properties of the polyurethane network due to the high enantio-, stereo-, and regioselectivity of the enzymes and a wide range of substrates [99]. The authors prepared polyurethanes by enzymatic transesterification of a urethane bond containing a monofunctional ester and a model alcohol carbitol using lipases. They concluded that the transesterification reaction worked optimally at $65^{\circ} \mathrm{C}$ for $24 \mathrm{~h}$. The low efficiency of the process can be increased by using an eightfold excess of carbitol compared with that of the monofunctional ester, which, however, is not very economical. Therefore, work on optimizing polyurethane biosynthesis still needs to be continued.

Interestingly, polyurethanes can also be part of the catalyst system [100]. An example is a nanobiocatalyst produced by immobilizing lipase B from Candida antarctica on nanoparticles based on polyurethane functionalized with poly(ethylene glycol) [101]. It was found that this nanocatalyst efficiently catalyzed the synthesis of eicosapentaenoic and docosahexaenoic acid esters, as well as the enantiomeric resolution of mandelic acid. This solution can be an important element of sustainable economy in the food and pharmaceutical industries. Additionally, Quezada et al. found that immobilization of the biocatalyst on polyurethane foam increases its catalytic efficiency in the reduction of ketones [102,103]. Moreover, Facin et al. used lipase immobilized on polyurethane foam to produce biodiesel from fatty industrial waste [104]. Moreover, to reduce methylene blue, polyurethane foam was used as a catalyst, in which ascorbic acid and fresh juice extracts were used as reducing agents [105]. The comparison of the efficiency of free and immobilized enzymes on polyurethane foam in relation to hydrolysis of soybean oil indicates a much higher catalytic efficiency of immobilized catalysts [106].

\section{Principle 10.}

Historically, polyurethanes are known for their resistance to external factors. This has made them popular in the industry, where resistance to acids, bases, oils, and heat is an extremely important issue. At the same time, however, this high resistance means that polyurethanes remain unchanged in the environment for so long. However, Matsumura, Soeda, and Toshima, in 2006, already pointed out the groups of bacteria, fungi, and enzymes capable of degrading the resistant urethane group [8]. Information on the sensitivity of polyurethanes to degrading agents was extended by Magnin et al. in 2020 [107].

By introducing appropriate groups into the structure of polyurethanes, materials susceptible to chemical hydrolysis, oxidation, and enzymatic degradation can be synthetized, even if they concern cross-linked polyurethanes, which are usually extremely resistant to 
external factors. By introducing hydrolyzable substrates (of natural or synthetic origin) into their structure, degradable materials are obtained [108].

Ferris et al., from 1,4-di-S-benzyl- $D, L$-dithiothreitol, triethylene glycol, and 1,6-hexamethylene diisocyanate, obtained polyurethanes susceptible to hydrolytic degradation (especially at $\mathrm{pH} 8$ ) and the action of enzymes papain, $\alpha$-chymotrypsin, cholesterol esterase, and lipase [109]. In contrast, Alvarez-Barragán et al. presented a series of species mainly belonging to Cladosporium cladosporioides that could degrade commercial polyesterand polyetherurethane varnishes and foams [110]. They proved that the ester and urethane groups in the structure of polyurethanes were sensitive to the action of fungal enzymes.

In the paper [111], there were discussed and characterized highly efficient microorganisms and degrading enzymes capable of breaking down polyurethane chains into oligo- and monomeric compounds. The main enzymes that were able to biodegrade polyurethanes were: esterases (e.g., from Comamonas acidovorans TB-35, Pseudomonas fluorescens), lipases (Pseudomonas chlororaphis), cutinases (Plant compost, Thermobifida fusca KW3, Thermomonospora curvata DSM43183), and urethane hydrolases (Rhodococcus equi TB-60). The microorganisms that degraded polyurethanes were, among others: Bacillus spp., Pseudomonas spp., Acinetobacter gerneri P7, Pseudomonas putida A12, Comamonas acidovorans TB-35, Aspergillus flavus (ITCC 6051), and Cladosporium pseudocladosporioides. The main techniques to assess the progress of polyurethane biodegradation were the gravimetric method, FTIR, SEM, $\mathrm{CO}_{2}$ evolution, DSC, Drop shape analysis system, HT-SEC GPC, ASTM S638-10 Instron, LC-MS, GC-MS, and NMR [111].

The most popular way to obtain biodegradable polyurethane is its modification with natural compounds which, under the influence of various environmental factors, can return to nature. Starch is an extremely popular material that already exists in commercial circulation. Unfortunately, this polymer has a limited use due to its very high hydrophilicity and brittleness. Therefore, its combination with a synthetic polymer makes it possible to obtain a new material with properties different from those of the original components. Due to the high hydrophilicity of starch, it can be modified to be compatible with much less hydrophilic polyurethane. Detailed interactions between starch and polyurethane chains were described by Tai et al. [112].

Polyurethanes based on isosorbide polymers and hexamethylene diisocyanate for use as implants were obtained in a simple, one-step reaction, without the use of catalysts [113]. The sample with the highest amount of isosorbidol reduced its weight by $5 \%$ after just two weeks of incubation in phosphate-buffered solution.

According to green chemistry, Principle 11, apart from the product's susceptibility to degradation, also covers their recyclability [11]. For many years, polyurethanes, especially polyurethane foams, have been recycled into polyols which are then used to obtain new foams $[111,114,115]$. As polyurethanes are thermally stable, the most advantageous method of recycling them is the chemical method. Especially glycolysis is important from an industrial point of view. Hydrolysis of polyurethanes, which requires the use of high energy for economic reasons, has not yet reached its importance on an industrial scale. Furthermore, the more environmentally friendly method of hydrolysis using the $\mathrm{CO}_{2}$ / water system at 8 $\mathrm{MPa}$ and $190^{\circ} \mathrm{C}$ turned out to be too energy-consuming to be attractive to industry [116]. Obtained during the aminolysis of polyurethane, methylene diphenyl amine is a monomer used for synthesis of poly(p-diphenylmethylterephthalamide), a polymer that is generally used to improve several properties of some polymers, such as Nylon 6 and Kevlar, and as a hardener for epoxy resin. It does not change the fact that the polyurethane aminolysis process is also not used on an industrial scale. Phosphorolysis of polyurethanes produces substrates that can be used in the production of flame retardant polyurethanes. However, this method of recycling is also still at the research, not industrial, stage. Thus, glycolysis is of the greatest importance in polyurethane recycling, among other methods. Polyurethane elastomers, coatings, and rigid and flexible foams are subject to glycolysis [116].

There are several companies in the world that manufacture polyols from polyurethane recyclates on an industrial scale. An interesting offer is presented by RAMPF, where as 
part of RAMPF Eco Solutions, it offers polyols from polyurethane residues, but also from polyesters such as polylactic acid and polyhydroxybutyrate, as well as biomonomers [117]. The BASF company from Germany expects to launch a pilot production of polyol from recyclate from polyurethane mattresses this year. BASF's researchers are also working on the recovery of the diisocyanate, which would be a significant achievement [118]. From an environmental point of view, research on the use of crude glycerol (biodiesel subproduct) as a cleaving agent in the process of polyurethane glycolysis is particularly important [116].

A very beneficial path for polyurethane recycling would be the use of biological methods. While it is successful for polyethylene terephthalate, it is difficult for polyurethanes because of their very high chemical structure diversity. However, there are attempts to bio-recycle polyurethanes (especially polyester urethanes) and obtain secondary products from the resulting recyclates. After incubation of 2,4-toluene diisocyanate and polycaprolactone based polyurethane foam in Candida Antarctica lipase B, Magnin et al. received 6-hydroxycaproic acid and a short diacid linked with diisocyanate. From these recovered building blocks, a new polyurethane with very satisfactory properties was obtained [119].

\section{Principle 11.}

Process control during polymer synthesis is necessary to prevent the formation of by-products, but also to prevent products of poor quality, which will not be suitable for use. The ongoing control of the polyurethane synthesis process is extremely important. Figure 11 shows a polyurethane elastomer film and a sample of the same composition but obtained with too little dehydrated polyol/diol. The water in the reaction mixture reacted with the isocyanate groups to form $\mathrm{CO}_{2}$, which was released to form bubbles during the film forming step.

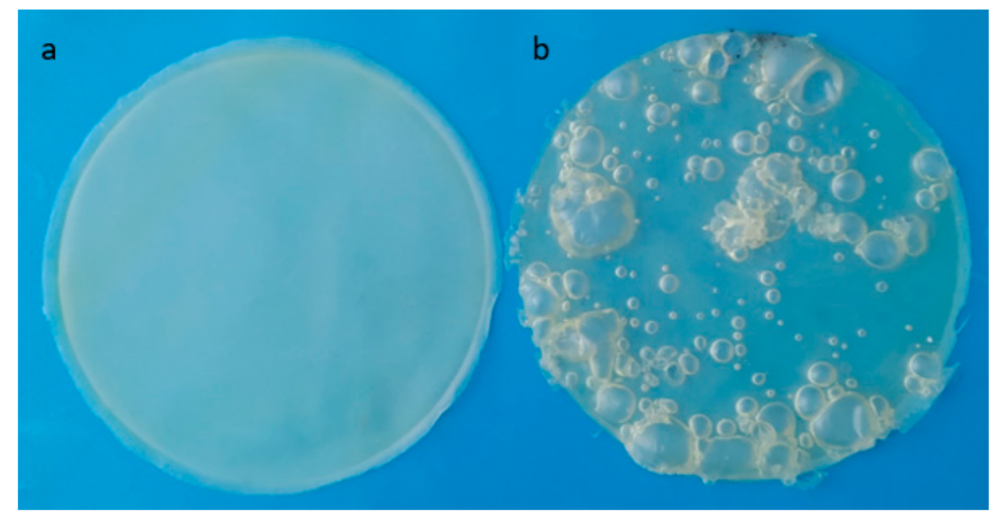

Figure 11. Picture of polyurethane elastomer (a) and a sample with the same, but poorly dehydrated substrates (b).

\section{Principle 12.}

Common sense, compliance with procedures, and knowledge of the properties of the substrates used allow for safe polyurethane synthesis processes, as evidenced by successfully and safely obtained polyurethane products, both in research laboratories and in industrial plants, as well as by individual consumers. However, there may be situations where, for example, insufficiently reduced pressure will lead to ignition of the diisocyanate during distillation or there may be situations where poorly maintained production lines lead to leakage of substrate.

Perhaps the most spectacular example of the monstrous neglect of substrate storage is the release of methylene isocyanate in Bhopal, India. This may not be directly related to the production of polyurethanes, but this event could have happened in different ways in any polyurethane company that produces isocyanates for their production. Union Carbide Corporation produced pesticides, incl. from methylene isocyanate. It is unlikely that the company's location was in the center of a city with a million people. In addition, 
for financial reasons and general negligence, the safety rules were ignored. As a result, the poisonous gas spread over an area of 25 kilometers in diameter, resulting in the deaths of 15,000 to 30,000 people and serious diseases in hundreds of thousands more people $[120,121]$.

Undoubtedly, the risk of its inflammation is an unquestionable threat related to the use of polyurethane. The rapid increase in deaths in the UK from fires, especially from toxic gases in the 1950s-1980s of the last century, was associated with an increase in polyurethane foams in furniture and construction [122]. As the temperature rises, gaseous products emerge from polyurethane: isocyanates, amines, and yellow smoke $\left(>300{ }^{\circ} \mathrm{C}\right)$; low molecular weight nitrogen fragments and polyol fragments $\left(>600^{\circ} \mathrm{C}\right)$; and $\mathrm{HCN}, \mathrm{CO}$, $\mathrm{CO}_{2}, \mathrm{NO}_{\mathrm{x}}, \mathrm{H}_{2} \mathrm{O}$, simple organic compounds and polycyclic aromatic hydrocarbons $\left(>800^{\circ} \mathrm{C}\right)$.

The main asphyxiant gases produced by the combustion of polyurethanes are $\mathrm{CO}$ and $\mathrm{HCN}$, as well as the isocyanates themselves, the toxicity of which is discussed in Principle 3.

It is therefore extremely important to protect flats and houses against the risk of fires, but also to use optimal polyurethane flame retardants. The flame-retardant polyurethane coating with good and versatile parameters (including the cold resistance and mechanical properties) can be produced by a simple and efficient method by introducing phosphorus and silicon units into waterborne polyurethane [123].

Separate issues related to environmentally friendly polyurethanes, which are not considered in this paper, are polyurethane use for nature treatment $[124,125]$ and their self-healing version [126].

\section{Future Perspectives and Conclusions}

What can be done to make polyurethanes greener?

The development of the polyurethane industry goes in one direction with the polymer industry in general. As shown in this work, the basic directions of changes, taking place during the synthesis of polyurethanes, are: (1) the use of non-toxic substrates and auxiliary compounds (solvents and catalysts); (2) obtaining products with appropriate strength during use but which degrade after their lifetime; and (3) the use of less energy-intensive processes. The modification of polyurethanes with compounds of natural origin is of significant importance. Their presence in the polyurethane network or in its chemical structure increases the non-toxicity and susceptibility to degradation in the environmental conditions of this material.

The presented results of the works of many authors show that much has already been done to make polyurethanes more environmentally friendly materials. Polyurethanes are already obtained very often in accordance with the principles of green chemistry. Perhaps, however, to obtain them, one should reach for such natural resources, which are currently useless agricultural or food post-production or post-consumer waste.

Author Contributions: Conceptualization, visualization, project administration, writing-original draft preparation, supervision, formal analysis, funding acquisition, writing-review and editing J.B. and A.P.-K. All authors have read and agreed to the published version of the manuscript.

Funding: This research was funded by UMG Research Project, grant number WZNJ/2021/PZ/02.

Institutional Review Board Statement: Not applicable.

Informed Consent Statement: Not applicable.

Data Availability Statement: Not applicable.

Conflicts of Interest: The authors declare no conflict of interest. 


\section{References}

1. American Chemistry Council-Center for the Polyurethanes Industry (CPI). Available online: https://polyurethane. americanchemistry.com/History/ (accessed on 21 August 2021).

2. Loreti, A.; Siri, G.; De Carli, M.; Fanelli, B.; Arelli, F.; Spallone, D.; Abate, O.; La Pinta, M.; Manna, E.; Meli, E.Z.; et al. Immediate Breast Reconstruction after mastectomy with polyurethane implants versus textured implants: A retrospective study with focus on capsular contracture. Breast 2020, 54, 127-132. [CrossRef] [PubMed]

3. Naemonitou, F.; Mylvaganam, S.; Salem, F.; Vidya, R. Outcome of complete acellular dermal matrix wrap with polyurethane implant in immediate prepectoral breast reconstruction. Arch. Plast. Surg. 2020, 47, 567-573. [CrossRef]

4. Cui, Z.X.; Shen, S.; Wu, J.H.; Si, J.H.; Wang, Q.T.; Turng, L.-S.; Chen, W.Z. Functionalization of 3-D porous thermoplastic polyurethane scaffolds by two-stage polydopamine/hydroxyapatite composite nanoparticles. Express Polym. Lett. 2020, 14, 794-807. [CrossRef]

5. Yang, J.; Chen, H.; Yuan, Y.; Sarkar, D.; Zheng, J. Synthesis and characterization of biocompatible polyurethanes for controlled release of hydrophobic and hydrophilic drugs. Front. Chem. Sci. Eng. 2014, 8, 498-510. [CrossRef]

6. González-Torres, M.; Serrano-Aguilar, I.H.; Cabrera-Wrooman, A.; Sánchez-Sánchez, R.; Pichardo-Bahena, R.; Melgarejo-Ramírez, Y.; Leyva-Gómez, G.; Cortés, H.; de los Angeles Moyaho-Bernal, M.; Lima, E.; et al. Gamma radiation-induced grafting of poly(2-aminoethyl methacrylate) onto chitosan: A comprehensive study of a polyurethane scaffold intended for skin tissue engineering. Carbohydr. Polym. 2021, 270, 117916. [CrossRef]

7. Shaabani, A.; Sedghi, R. Synthesis of shape memory electroconductive polyurethane with self-healing capability as an intelligent biomedical scaffold for bone tissue engineering. Polymer 2021, 223, 123694. [CrossRef]

8. Matsumura, S.; Soeda, Y.; Toshima, K. Perspectives for synthesis and production of polyurethanes and related polymers by enzymes directed toward green and sustainable chemistry. Appl. Microbiol. Biotechnol. 2006, 70, 12-20. [CrossRef]

9. Sheldon, R. Metrics of Green Chemistry and Sustainability: Past, Present, and Future. ACS Sustain. Chem. Eng. 2017, 6, 32-48. [CrossRef]

10. Bodner, G.M. The quadruple bottom line: The advantages of incorporating Green Chemistry into the undergraduate chemistry major. In Green Chemical Processes: Developments in Research and Education; Benvenuto, M.A., Ed.; Walter de Gruyter GmbH: Berlin, Germany; Boston, MA, USA, 2017.

11. Etzkorn, F.A. Green Chemistry. Principles and Case Study; The Royal Society of Chemistry: London, UK, 2020; pp. XI-XIII.

12. FACTS Hazardous Materials Accidents Knowledge Base. Available online: http://www.factsonline.nl/accidents/\%205405/1015 8_POLYURETHANE\%20FOAM/chemical-accidents-with-polyurethane-foam (accessed on 21 August 2021).

13. Association for the Study of Failure-Self-Ignition of Soft Urethane Foam on Restarting Operation after Maintenance at a Depot. Available online: http:/ / www.shippai.org/fkd/en/cfen/CC1000063.html (accessed on 20 August 2021).

14. Palumbo, F.S.; Federico, S.; Pitarresi, G.; Fiorica, C.; Giammona, G. Synthesis and characterization of redox-sensitive polyurethanes based on L-glutathione oxidized and poly(ether ester) triblock copolymers. React. Funct. Polym. 2021, 166, 104986. [CrossRef]

15. Błażek, K.; Kasprzyk, P.; Datta, J. Diamine derivatives of dimerized fatty acids and bio-based polyether polyol as sustainable platforms for the synthesis of non-isocyanate polyurethanes. Polymer 2020, 205, 112768. [CrossRef]

16. Chan, J.P.; Battiston, K.G.; Santerre, J.P. Synthesis and characterization of electrospun nanofibrous tissue engineering scaffolds generated from in situ polymerization of ionomeric polyurethane composites. Acta Biomater. 2019, 96, 161-174. [CrossRef]

17. Munn, A. Hazards of isocyanates. Ann. Occup. Hyg. 1965, 8, 163-169.

18. Tanser, A.R.; Bourke, M.P.; Blandford, A.G. Isocyanate asthma: Respiratory symptoms caused by diphenyl-methane di-isocyanate. Thorax 1973, 28, 596-600. [CrossRef]

19. Bello, D.; Herrick, C.A.; Smith, T.J.; Woskie, S.R.; Streicher, R.P.; Cullen, M.R.; Liu, Y.; Redlich, C.A. Skin Exposure to Isocyanates: Reasons for Concern. Environ. Health Perspect. 2007, 115, 328-335. [CrossRef] [PubMed]

20. Mukai, M.; Woods, L.W.; Stump, S.; Ebel, J.G., Jr.; Levitt, A.S.; Frey, M.W.; Smith, J.; Uzal, F.A.; Poppenga, R.H.; Puschner, B. Detection of diisocyanates in nesting material associated with mortality in pigeon chicks. J. Vet. Diagn. Investig. 2014, 26, 327-333. [CrossRef] [PubMed]

21. Xiang, F.; Yin, J.; Asri, L.; Loontjens, T. Functional polyurethanes based on blocked isocyanates. In Polyurethanes; Hope, F.L., Ed.; Nova Science Publishers, Inc.: Hauppauge, NY, USA, 2016; pp. 1-16.

22. Waghmare, B.; Mahanwar, P. Review on synthesis of isocyanate free polyurethane using sustainable routes and its applications. Paintindia 2019, 83-98. Available online: https://colourpublications.in/product/paintindia/ (accessed on 21 August 2021).

23. Lambeth, R.H. Progress in Hybrid Non-Isocyanate Polyurethanes. Polym. Int. 2021, 70, 696-700. [CrossRef]

24. Gomez-Lopez, A.; Grignard, B.; Calvo, I.; Detrembleur, C.; Sardon, H. Synergetic Effect of Dopamine and Alkoxysilanes in Sustainable Non-Isocyanate Polyurethane Adhesives. Macromol. Rapid Commun. 2020, 42, 2000538. [CrossRef]

25. Filippi, L.; Meier, M.A.R. Fully renewable non-isocyanate polyurethanes via the lossen rearrangement. Macromol. Rapid Commun. 2021, 42, 2000440. [CrossRef] [PubMed]

26. Wu, H.; Jin, B.; Wang, H.; Wu, W.; Cao, Z.; Wu, J.; Huang, G. A Degradable and Self-Healable Vitrimer Based on Non-isocyanate Polyurethane. Front. Chem. 2020, 8, 585569. [CrossRef] [PubMed]

27. Wang, D.; Chen, S.; Zhao, J.; Zhang, Z. Synthesis and characterization of self-healing cross-linked non-isocyanate polyurethanes based on Diels-Alder reaction with unsaturated polyester. Mater. Today Commun. 2020, 23, 101138. [CrossRef] 
28. Wolfgang, J.D.; White, B.T.; Long, T.E. Non-isocyanate Polyurethanes from 1,1'-Carbonyldiimidazole: A Polycondensation Approach. Macromol. Rapid Commun. 2021, 42, 2100163. [CrossRef]

29. Boisaubert, P.; Kébir, N.; Schuller, A.-S.; Burel, F. Photo-crosslinked coatings from an acrylate terminated non-isocyanate polyurethane (NIPU) and reactive diluent. Eur. Polym. J. 2020, 138, 109961. [CrossRef]

30. Wu, Z.; Tang, L.; Dai, J.; Jinqing, Q.J. Synthesis and properties of fluorinated non-isocyanate polyurethanes coatings with good hydrophobic and oleophobic properties. J. Coat. Technol. Res. 2019, 16, 1233-1241. [CrossRef]

31. Zareanshahraki, F.; Asemani, H.R.; Skuza, J.; Mannari, V. Synthesis of non-isocyanate polyurethanes and their application in radiation-curable aerospace coatings. Progr. Org. Coat. 2020, 138, 105394. [CrossRef]

32. Kanchana, R. Review of Eco friendly green polyurethanes with non-isocyanates: Current and future trends in green coatings. Paintindia 2017, 55-79. Available online: https:// colourpublications.in/product/paintindia/ (accessed on 21 August 2021).

33. Monie, F.; Grignard, B.; Thomassin, J.-M.; Mereau, R.; Thierry Tassaing, T.; Jerome, C.; Detrembleur, C. Chemo- and regioselective additions of nucleophiles to cyclic carbonates for the preparation of self-blowing non-isocyanate polyurethane foams. Angew. Chem. Int. Ed. 2020, 132, 17181-17189. [CrossRef]

34. Gholami, H.; Yeganeh, H. Soybean oil-derived non-isocyanate polyurethanes containing azetidinium groups as antibacterial wound dressing membranes. Eur. Polym. J. 2021, 142, 110142. [CrossRef]

35. Stachak, P.; Łukaszewska, I.; Hebda, E.; Pielichowski, K. Recent Advances in Fabrication of Non-Isocyanate Polyurethane-Based Composite Materials. Materials 2021, 14, 3497. [CrossRef]

36. Wołosz, D.; Parzuchowski, P.G.; Świderska, A. Synthesis and characterization of the non-isocyanate poly(carbonate-urethane)s obtained via polycondensation route. Eur. Polym. J. 2021, 155, 110574. [CrossRef]

37. Kohale, D.G. Recent developments in water base paint for automotive paints. Paintindia 2018, 62-68. Available online: https: / / colourpublications.in/product/paintindia/ (accessed on 21 August 2021).

38. Agnol, L.D.; Dias, F.T.G.D.; Ornaghi, H.L., Jr.; Sangermano, M.; Bianchi, O. UV-curable waterborne polyurethane coatings: A state-of-the-art and recent advances review. Prog. Org. Coat. 2021, 154, 106156. [CrossRef]

39. Gong, R.; Cao, H.; Zhang, H.; Qiao, L.; Wang, X. UV-curable cationic waterborne polyurethane from $\mathrm{CO}_{2}$-polyol with excellent water resistance. Polymer 2021, 218, 123536. [CrossRef]

40. Wei, Z.; Liu, Z.; Fu, X.; Wang, Y.; Yuan, A.; Lei, J. Effect of crystalline structure on water resistance of waterborne polyurethane. Eur. Polym. J. 2021, 157, 110647. [CrossRef]

41. Zhang, Z.; Peng, P.; Wu, Q.; Zhang, J.; Wu, M.; Liu, J.; Yang, J. Preparation and antibacterial properties of poly(hexamethylene guanidine hydrochloride) modified ionic waterborne polyurethane. Prog. Org. Coat. 2021, 156, 106246. [CrossRef]

42. Peng, X.; Liu, Y.; Xin, B.; Guo, H.; Yu, Y. Preparation and characterization of waterborne polyurethane nail enamel modified by silane coupling agent. J. Coat. Technol. Res. 2020, 17, 1377-1387. [CrossRef]

43. Liu, Z.; Chen, H.; Hu, G.; Wang, J.; Xin, Y.; Xiang, C.; Zhou, Y. Excellent water resistance and mechanically robust waterborne polyurethane-acrylate based on dithiol post-chain extension. J. Coat. Technol. Res. 2020, 17, 1065-1074. [CrossRef]

44. Xu, W.; Wang, W.; Hao, L.; Liu, H.; Hai, F.; Wang, X. Synthesis and properties of novel triazine-based fluorinated chain extender modified waterborne polyurethane hydrophobic films. Prog. Org. Coat. 2021, 157, 106282. [CrossRef]

45. Stefanović, I.S.; Džunuzović, J.V.; Džunuzović, E.S.; Brzić, S.J.; Jasiukaitytè-Grojzdek, E.; Basagni, A.; Marega, C. Tailoring the properties of waterborne polyurethanes by incorporating different content of poly(dimethylsiloxane). Prog. Org. Coat. 2021, 161, 106474. [CrossRef]

46. Wu, J.; Wang, C.; Lin, W.; Ngai, T. A facile and effective approach for the synthesis of fluorinated waterborne polyurethanes with good hydrophobicity and antifouling properties. Prog. Org. Coat. 2021, 159, 106405. [CrossRef]

47. Longfang, R.; Congcong, L.; Pingchuan, L. Preparation and properties of catechol-based waterborne polyurethane based on thiol-ene click chemistry reaction. Prog. Org. Coat. 2021, 157, 106303.

48. Wang, X.; Cui, Y.; Wang, Y.; Ban, T.; Zhang, Y.; Zhang, J.; Zhu, X. Preparation and characteristics of crosslinked fluorinated acrylate modified waterborne polyurethane for metal protection coating. Prog. Org. Coat. 2021, 158, 106371. [CrossRef]

49. Shan, J.; Jiang, L.; Wang, L.; Zhao, H.; Ding, X.; Zhou, C. Improvement of low-temperature damping performance by the control of three-dimensional network structure formed by renewable oil in modified waterborne polyurethane. Results Mater. 2021, 10, 100171. [CrossRef]

50. Qian, Y.; Dong, F.; Guo, L.; Xu, X.; Liu, H. Terpene derivative-containing silicone two-component waterborne polyurethane for coatings. Prog. Org. Coat. 2021, 153, 106137. [CrossRef]

51. Chen, Y.; Yu, Z.; Oguzlu, H.; Jiang, J.; Cho, M.; Karaaslan, M.; Renneckar, S.; Jiang, F. Superelastic and flexible 3D printed waterborne polyurethane/cellulose nanofibrils structures. Addit. Manuf. 2021, 46, 102107.

52. Fan, W.; Wang, J.; Li, Z. Antiglare waterborne polyurethane/modified silica nanocomposite with balanced comprehensive properties. Polym. Test. 2021, 99, 107072. [CrossRef]

53. Bramhecha, I.; Sheikh, J. Antibacterial and waterproof breathable waterborne polyurethane functionalised by graphene to develop UV and NIR-protective cotton fabric. Carbon Trends 2021, 4, 100067. [CrossRef]

54. Smith, C.A.; Cramail, H.; Tassaing, T. Insights into the Organocatalyzed Synthesis of Urethanes in Supercritical Carbon Dioxide: An In Situ FTIR Spectroscopic Kinetic Study. Chem. Cat. Chem. 2014, 6, 1380-1391. [CrossRef]

55. Ihata, O.; Kayaki, Y.; Ikariya, T. Synthesis of Thermoresponsive Polyurethane from 2-Methylaziridine and Supercritical Carbon Dioxide. Angew. Chem. Int. Ed. 2004, 43, 717-719. [CrossRef] 
56. Wang, J.; Li, J.; Li, H.; Zhou, H. Thermoplastic polyurethane (TPU) modifier to develop bimodal cell structure in polypropylene/TPU microcellular foam in presence of supercritical $\mathrm{CO}_{2}$. J. Vinyl. Addit. Technol. 2021, 27, 127-136. [CrossRef]

57. Huang, A.; Wang, H.; Ellingham, T.; Peng, X.; Turng, L.-S. An improved technique for dispersion of natural graphite particles in thermoplastic polyurethane by sub-critical gas-assisted processing. Comp. Sci. Tech. 2019, 182, 107783. [CrossRef]

58. Primel, A.; Férec, J.; Ausias, G.; Tirel, Y.; Veillé, J.-M.; Grohens, Y. Solubility and interfacial tension of thermoplastic polyurethane meltin supercritical carbon dioxide and nitrogen. J. Supercrit. Fluids 2017, 122, 52-57. [CrossRef]

59. Yang, Z.; Liu, T.; Hu, D.; Xu, Z.; Zhao, L. Foaming window for preparation of microcellular rigid polyurethanes using supercritical carbon dioxide as blowing agent. J. Supercrit. Fluids 2019, 147, 254-262. [CrossRef]

60. Wang, W.; Liao, X.; Yusong, H.; Li, J.; Jiang, Q.; Li, G. Thermoplastic polyurethane/polytetrafluoroethylene composite foams with enhanced mechanical properties and anti-shrinkage capability fabricated with supercritical carbon dioxide. J. Supercrit. Fluids 2020, 163, 104861. [CrossRef]

61. Savaris, M.; Garcia, C.S.C.; Roesch-Ely, M.; Henriques, J.A.P.; dos Santos, V.; Brandalise, R.N. Polyurethane/poly(D,L-lactic acid) scaffolds based on supercritical fluid technology for biomedical applications: Studies with L929 cells. Mat. Sci. Eng. C 2019, 96, 539-551. [CrossRef] [PubMed]

62. Qu, Z.; Yin, D.; Zhou, H.; Wang, X.; Zhao, S. Cellular morphology evolution in nanocellular poly (lactic acid)/thermoplastic polyurethane blending foams in the presence of supercritical $\mathrm{N}_{2}$. Europ. Polym. J. 2019, 116, 291-301. [CrossRef]

63. Filardo, G.; Galia, A.; Gambino, S.; Silvestri, G. Supercritical-Fluid Extraction of Chlorofluoroalkanes from Rigid Polyurethane Foams. J. Supercrit. Fluids 1996, 9, 234-237. [CrossRef]

64. Chen, S.-C.; Chang, C.-W.; Tseng, C.Y.; Shen, E.-N.; Feng, C.-T. Using P(Pressure)-T(Temperature) Path to Control the Foaming Cell Sizes in Microcellular Injection Molding Process. Polymers 2021, 13, 1843. [CrossRef]

65. Sirrine, J.M.; Ashraf-Khorassani, M.; Moon, N.G.; Mondschein, R.J.; Long, T.E. Supercritical Fluid Chromatography with Evaporative Light Scattering Detection (SFC-ELSD) for Determination of Oligomer Molecular Weight Distributions. Chromatographia 2016, 79, 977-984. [CrossRef]

66. Biswas, A.; Appell, M.; Liu, Z.; Cheng, H.N. Microwave-assisted synthesis of cyclodextrin polyurethanes. Carbohydr. Polym. 2015, 133, 74-79. [CrossRef]

67. Lubczak, R. New Method of Synthesis of Oligoetherols with Carbazole Ring. Acta Chim. Slov. 2015, 62, 652-661. [CrossRef]

68. Boisaubert, P.; Kébir, N.; Schuller, A.-S.; Burel, F. Photo-crosslinked Non-Isocyanate Polyurethane Acrylate (NIPUA) coatings through a transurethane polycondensation approach. Polymer 2020, 206, 122855. [CrossRef]

69. Peyton, J.; Avérous, L. Structure-properties relationships of cellular materials from biobased polyurethane foams. Mater. Sci. Eng. $R$ 2021, 145, 100608. [CrossRef]

70. Morales-Cerrada, R.; Tavernier, R.; Caillol, S. Fully Bio-Based Thermosetting Polyurethanes from Bio-Based Polyols and Isocyanates. Polymers 2021, 13, 1255. [CrossRef]

71. Noreen, A.; Zia, K.M.; Zuber, M.; Tabasum, S.; Zahoor, A.F. Bio-based polyurethane: An efficient and environment friendly coating systems: A review. Prog. Org. Coat. 2016, 91, 25-32. [CrossRef]

72. Llevot, A.; Meier, M. Perspective: Green polyurethane synthesis for coating applications. Polym. Int. 2019, 68, 826-831. [CrossRef]

73. Bresolin, D.; Estrella, A.S.; da Silva, J.R.P.; Valério, A.; Sayer, C.; de Araújo, P.H.H.; de Oliveira, D. Synthesis of a green polyurethane foam from a biopolyol obtained by enzymatic glycerolysis and its use for immobilization of lipase NS-40116. Bioprocess Biosyst. Eng. 2019, 42, 213-222. [CrossRef]

74. Isbell, T.A.; Lowery, B.A.; DeKeyser, S.S.; Winchell, M.L.; Cermak, S.C. Physical properties of triglyceride estolides from lesquerella and castor oils. Ind. Crop. Prod. 2006, 23, 256-263. [CrossRef]

75. Petrović, Z.S. Polyurethanes from Vegetable Oils. Polym. Rev. 2008, 48, 109-155. [CrossRef]

76. Bundjali, B.; Masykuri, M.; Hartantini, F.W.; Arcana, M. Poly(urethane-urea) synthetised from 9-ethoxy-1,10-octadecanediol obtained by modification of palm oil oleic acid. J. Math. Fund. Sci. 2018, 50, 13-27. [CrossRef]

77. Mohammed, I.A.; Khadir, N.K.A.; Al-Murra, E.A.J. New polyurethane nanocomposites based on soya oil. J. Oleo Sci. 2014, 63, 193-200. [CrossRef]

78. Wang, C.; Zhang, J.; Huang, J.; Wang, H.; He, M.; Ding, L. Flame Retardant Modified Bio-Based Waterborne Polyurethane Dispersions Derived from Castor Oil and Soy Polyol. Eur. J. Lipid Sci. Technol. 2021, 123, 2000248. [CrossRef]

79. Karimi, M.B.; Khanbabaeib, G.; Sadeghi, C.M.M. Vegetable oil-based polyurethane membrane for gas separation. J. Membr. Sci. 2017, 527, 198-206. [CrossRef]

80. Kurth, T.M.; Kurth, R.A.; Turner, R.B.; Kreifels, L.P. Vegetable Oil-Based Coating and Method for Application. U.S. Patent 8575226, 4 December 2001.

81. Aristri, M.A.; Lubis, M.A.R.; Yadav, S.M.; Antov, P.; Papadopoulos, A.N.; Pizzi, A.; Fatriasari, W.; Ismayati, M.; Iswanto, A.H. Recent Developments in Lignin- and Tannin-Based Non-Isocyanate Polyurethane Resins for Wood Adhesives-A Review. Appl. Sci. 2021, 11, 4242. [CrossRef]

82. Klein, S.E.; Rumpf, J.; Alzagameem, A.; Rehahn, M.; Schulze, M. Antioxidant activity of unmodified kraft and organosolv lignins to be used as sustainable components for polyurethane coatings. J. Coat. Technol. Res. 2019, 16, 1543-1552. [CrossRef]

83. Visco, A.; Nocita, D.; Giamporcaro, A.; Ronca, S.; Forte, G.; Pistone, A.; Espro, C. Effect of Ethyl Ester L-Lysine Triisocyanate addition to produce reactive PLA/PCL bio-polyester blends for biomedical applications. J. Mech. Behav. Biomed. Mater. 2017, 68, 308-317. [CrossRef] [PubMed] 
84. Gu, R.; Sain, M. Biobased Polyurethanes in Handbook of Green Materials: Processing Technologies, Properties and Applications; Oksman, K., Mathew, A.P., Bismarck, A., Rojas, O., Sain, M., Eds.; World Scientific Publishing Company: Singapore, 2014 ; pp. $77-87$.

85. Da Silva, F.C.; Felgueiras, H.P.; Ladchumananandasivam, R.; Mendes, J.U.L.; de O Souto Silva, K.K.; Zille, A. Dog wool microparticles/polyurethane composite for thermal insulation. Polymers 2020, 12, 1098. [CrossRef] [PubMed]

86. Alonso-Lerma, B.; Larraza, I.; Barandiaran, L.; Ugarte, L.; Saralegi, A.; Corcuera, M.A.; Perez-Jimenez, R.; Eceiza, A. Enzymatically produced cellulose nanocrystals as reinforcement for waterborne polyurethane and its applications. Carbohydr. Polym. 2021, 254, 117478. [CrossRef] [PubMed]

87. Alma, M.H.; Salan, T.; Tozluoglu, A.; Gonultas, O.; Candan, Z. Green composite materials from liquefied biomass. In Green Composites: Materials, Manufacturing and Engineering; Davim, J.P., Ed.; Walter de Gruyter GmbH: Berlin, Germany; Boston, MA, USA, 2017; pp. 1-31.

88. Silva Araújo, R.C.; Duarte Pasa, V.M.; Marriott, P.J.; Cardeal, Z.L. Analysis of volatile organic compounds in polyurethane coatings based on Eucalyptus sp. bio-oil pitch using comprehensive two-dimensional gas chromatography (GC $\times$ GC). J. Anal. Appl. Pyrolysis 2010, 88, 91-97. [CrossRef]

89. Sarojini, S.K.; Indumathi, M.P.; Rajarajeswari, G.R. Mahua oil-based polyurethane/chitosan/nano ZnO composite films for biodegradable food packaging applications. Int. J. Biol. Macromol. 2019, 124, 163-174.

90. Ghasemlou, M.; Daver, E.; Ivanova, E.P.; Brkljaca, R.; Adhikari, B. Assessment of interfacial interactions between starch and non-isocyanate polyurethanes in their hybrids. Carbohydr. Polym. 2020, 246, 116656. [CrossRef] [PubMed]

91. Ghasemlou, M.; Daver, E.; Ivanova, E.P.; Brkljaca, R.; Adhikari, B. Synthesis of green hybrid materials using starch and nonisocyanate polyurethanes. Carbohyd. Polym. 2020, 229, 115535. [CrossRef]

92. Kiss, G.; Rusu, G.; Bandur, G.; Hulka, I.; Romecki, D.; Péter, F. Advances in Low-Density Flexible Polyurethane Foams by Optimized Incorporation of High Amount of Recycled Polyol. Polymers 2021, 13, 1736. [CrossRef]

93. Nikulin, M.; Švedas, V. Prospects of Using Biocatalysis for the Synthesis and Modification of Polymers. Molecules 2021, 26, 2750. [CrossRef] [PubMed]

94. Bresolin, D.; Hawerroth, B.; de Oliveira Romera, C.; Sayer, C.; de Araújo, P.H.H.; de Oliveira, D. Immobilization of lipase Eversa Transform 2.0 on poly(urea-urethane) nanoparticles obtained using a biopolyol from enzymatic glycerolysis. Bioprocess Biosyst. Eng. 2020, 43, 1279-1286. [CrossRef]

95. de Lima, A.P.D.; Aschenbrenner, E.M.; Oliveira, S.N.; Doucet, J.B.; Weiss, C.K.; Ziener, U.; Fonseca, L.P.; Ricardo, N.M.P.S.; de Freitas, L.L.; Petzhold, C.L.; et al. Towards regioselective enzymatic hydrolysis and glycerolysis of tricaprylin in miniemulsion and the direct preparation of polyurethane from the hydrolysis products. J. Mol. Catal. B Enzym. 2013, 98, 127-137. [CrossRef]

96. Baraldi, S.; Fantin, G.; Di Carmine, G.; Ragno, D.; Brandolese, A.; Massi, A.; Bortolini, O.; Marchetti, N.; Giovannini, P.P. Enzymatic synthesis of biobased aliphatic-aromatic oligoesters using 5,5'-bis(hydroxymethyl) furoin as a building block. RSC Adv. 2019, 9, 29044-29050. [CrossRef]

97. Arrieta, M.P.; Barrera Rivera, K.A.; Salgado, C.; Richa, A.M.; López, D.; Peponi, L. Degradation under composting conditions of lysine-modified polyurethane based on PCL obtained by lipase biocatalysis. Polym. Degrad. Stab. 2018, 152, 139-146. [CrossRef]

98. Hayashi, H.; Yanagishita, Y.; Matsumura, S. Chemoenzymatic Synthesis and Chemical Recycling of Poly(ester-urethane)s. Int. J. Mol. Sci. 2011, 12, 5490-5507. [CrossRef]

99. Skoczinski, P.; Espinoza Cangahuala, M.K.; Maniar, D.; Loos, K. Enzymatic transesterification of urethane-bond containing ester Enzymatic transesterification of urethane-bond containing ester. Colloid Polym. Sci. 2021, 299, 561-573. [CrossRef]

100. Moentamaria, D.; Dewajani, H.; Chumaidi, A.; Nurmahdi, H.; Sinduwati, C. Heterogeneous biocatalyst: Polyurethane foam coating technique with co-immobilized lipase for bio-flavor production. Mat. Sci. Eng. 2020, 732, 012003. [CrossRef]

101. Cipolatti, E.P.; Valério, A.; Henriques, R.O.; Pinto, M.C.C.; Lorente, G.F.; Manoel, E.A.; Guisán, J.M.; Ninowa, J.L.; de Oliveira, D.; Pessela, B.C. Production of new nanobiocatalysts via immobilization of lipase B from C. antarctica on polyurethane nanosupports for application on food and pharmaceutical industries. Int. J. Biol. Macromol. 2020, 165, 2957-2963. [CrossRef] [PubMed]

102. Quezada, M.A.; Carballeira, J.D.; Sinisterra, J.V. Monascus kaoliang CBS 302.78 immobilized in polyurethane foam using iso-propanol as co-substrate: Optimized immobilization conditions of a fungus as biocatalyst for the reduction of ketones. Bioresour. Technol. 2009, 100, 2018-2025. [CrossRef] [PubMed]

103. Quezada, M.A.; Carballeira, J.D.; Sinisterra, J.V. Diplogelasinospora grovesii IMI 171018 immobilized in polyurethane foam. An efficient biocatalyst for stereoselective reduction of ketones. Bioresour. Technol. 2012, 112, 18-27. [CrossRef]

104. Facin, B.R.; Valério, A.; de Oliveira, D.; Oliveira, J.V. Developing an immobilized low-cost biocatalyst for FAME synthesis. Biocatal. Agric. Biotechnol. 2020, 29, 101752. [CrossRef]

105. Sultan, M.; Waheed, A.; Bibi, I.; Islam, A. Ecofriendly reduction of methylene blue with polyurethane catalyst. Int. J. Polym. Sci. 2019, 2019, 3168618. [CrossRef]

106. Facin, B.R.; Valério, A.; Bresolin, D.; Centenaro, G.; de Oliveira, D.; Oliveira, V. Improving reuse cycles of Thermomyces lanuginosus lipase (NS-40116) by immobilization in flexible polyurethane. Biocatal. Biotransfor. 2018, 36, 372-380. [CrossRef]

107. Magnin, A.; Pollet, E.; Phalip, V.; Avérous, L. Evaluation of biological degradation of polyurethanes. Biotech. Adv. 2020, 39 , 107457. [CrossRef] [PubMed]

108. Brzeska, J. Biodegradable polyurethanes cross-linked by multifunctional compounds. Curr. Org. Synth. 2017, 14, 778-784. [CrossRef]

109. Ferris, C.; de Paz, M.V.; Zamora, F.; Galbis, J.A. Dithiothreitol-based polyurethanes. Synthesis and degradation studies. Polym. Degrad. Stab. 2010, 95, 1480-1487. [CrossRef] 
110. Álvarez-Barragán, J.; Domínguez-Malfavón, L.; Vargas-Suárez, M.; González-Hernández, R.; Aguilar-Osorio, G.; Loza-Tavera, H. Biodegradative Activities of Selected Environmental Fungi on a Polyester Polyurethane Varnish and Polyether Polyurethane Foams. Appl. Env. Microbiol. 2016, 82, 5225-5235. [CrossRef] [PubMed]

111. Liu, J.; He, J.; Xue, R.; Xu, B.; Qian, X.; Xin, F.; Blank, L.M.; Zhou, J.; Wei, R.; Dong, W.; et al. Biodegradation and up-cycling of polyurethanes: Progress, challenges, and prospects. Biotech. Adv. 2021, 48, 107730. [CrossRef]

112. Tai, N.L.; Ghasemlou, M.; Adhikari, R.; Adhikari, B. Starch-based isocyanate- and non-isocyanate polyurethane hybrids: A review on synthesis, performance and biodegradation. Carbohyd. Polym. 2021, 265, 118029. [CrossRef] [PubMed]

113. Park, H.; Gong, M.-S.; Knowles, J.C. Catalyst-free synthesis of high elongation degradable polyurethanes containing varying ratios of isosorbide and polycaprolactone: Physical properties and biocompatibility. J. Mater. Sci. Mater. Med. 2013, 24, 281-294. [CrossRef] [PubMed]

114. Zia, K.M.; Bhatti, H.B.; Bhatti, I.A. Methods for polyurethane and polyurethane composites, recycling and recovery: A review. React. Funct. Polym. 2007, 67, 675-692. [CrossRef]

115. Kang, J.J.; Lee, J.S.; Yang, W.S.; Park, S.W.; Alam, M.T.; Back, S.K.; Choi, H.S.; Seo, Y.C.; Yun, Y.S.; Gub, J.H.; et al. A study on environmental assessment of residue from gasification of polyurethane waste in e-waste recycling process. Procedia Environ. Sci. 2016, 35, 639-642. [CrossRef]

116. Simón, D.; Borreguero, A.M.; de Lucas, A.; Rodríguez, J.F. Recycling of polyurethanes from laboratory to industry, a journey towards the sustainability. Waste Manag. 2018, 76, 147-171. [CrossRef]

117. RAMPF Discover the Future. “Tailor-Made Recycled Polyols and Manufacturing Plants" by RAMPF Eco Solutions. Available online: https:/ /www.rampf-group.com/en-us/company/rampf-core-competencies/eco-solutions/ (accessed on 21 October 2021).

118. C\&EN Chemical \& Engineering News. "BASF Advances Chemical Polyurethane Recycling" by Craig Bettenhausen. Available online: https:/ / cen.acs.org/environment/recycling/BASF-advances-chemical-polyurethane-recycling/98/i26 (accessed on 21 October 2021).

119. Magnin, A.; Entzmann, L.; Bazin, A.; Pollet, E.; Avérousm, L. Green Recycling Process for Polyurethane Foams by a Chem-Biotech Approach. ChemSusChem 2021, 14, 4234-4241. [CrossRef]

120. Gendek, T. Bhopal—zapomniana katastrofa (in Polish). Kwart. Chem. 2019, 4, 38-41.

121. European Parliament resolution on Bhopal. Official Journal of the European Union C 226 E/361, 16 December 2004. Available online: https: / / eur-lex.europa.eu/legal-content/EN/TXT/PDF/?uri=CELEX:52004IP0114 (accessed on 21 August 2021).

122. McKenna, S.T.; Hullm, T.R. The fire toxicity of polyurethane foams. Fire Sci. Rev. 2016, 5, 3. [CrossRef]

123. Cui, M.; Li, J.; Chen, X.; Hong, W.; Chen, Y.; Xiang, J.; Yan, J.; Fan, H. A halogen-free, flame retardant, waterborne polyurethane coating based on the synergistic effect of phosphorus and silicon. Prog. Org. Coat. 2021, 158, 106359. [CrossRef]

124. Ren, L.; Tang, Z.; Du, J.; Chen, L.; Qiang, T. Recyclable polyurethane foam loaded with carboxymethyl chitosan for adsorption of methylene blue. J. Hazard. Mater. 2021, 417, 126130. [CrossRef] [PubMed]

125. Piotrowska-Kirschling, A.; Szelagowska-Rudzka, K.; Karczewski, J.; Brzeska, J. Application of shrimp waste for the synthesis of polyurethane-chitosan materials with potential use in sorption of oil micro-spills in water treatment. Sustainability 2021, $13,5098$. [CrossRef]

126. Fan, C.-J.; Huang, Z.-C.; Li, B.; Xiao, W.-X.; Zheng, E.; Yang, K.K.; Wang, Y.Z. A robust self-healing polyurethane elastomer: From $\mathrm{H}$-bonds and stacking interactions to well-defined microphase morphology. Sci. China Mater. 2019, 62, 1188-1198. [CrossRef] 